\title{
What Is Still Necessary for Supporting the SDG7 in the Most Vulnerable Contexts?
}

\author{
Andrea A. Eras-Almeida *(-) and Miguel A. Egido-Aguilera \\ Instituto de Energía Solar, ETSI Telecomunicación, Universidad Politécnica de Madrid, Av. Complutense 30, \\ 28040 Madrid, Spain; egido@ies.upm.es \\ * Correspondence: andrea.eras@ies.upm.es; Tel.: +34-910-672-643
}

Received: 5 August 2020; Accepted: 31 August 2020; Published: 2 September 2020

\begin{abstract}
The common agreement of the United Nation members pushes the 2030 Agenda ahead to alleviate poverty and ensure wellbeing for all, recognizing energy as a crucial pathway to achieving this goal under three core dimensions: human development, sustainable economic growth, and environmental sustainability. Affordable and clean energy is represented by the Sustainable Development Goal 7 (SDG7). This great scope represents a multifaceted challenge for all countries, especially for the most disadvantaged environments such as small islands and rural areas from developing countries. Both small islands and rural areas experience a scarcity of goods and services such as energy and are isolated from markets, have lack of human resources, difficulties in deploying economies of scale, and other issues that affect their development. Along the same line, their energy security is limited by their dependence on imported fuels, increasing electricity prices or making it infeasible to access electricity. This research builds the state of the art of off-grid energy systems for both contexts based on an extensive review of literature. The evidence shows that moving sustainable energy systems forward requires getting more people involved, the application of several business models, prevalent technological innovations, and the application of technical quality procedures. This perspective would really help to address the vulnerabilities of fragile locations. Here, auctions, the Energy Service Company, community, and Pay-As-You-Go (PAYG) models and renewable energy projects based on mature technology present a great opportunity for a sustainable future, powering a nexus among energy, environment, and society.
\end{abstract}

Keywords: SDG7; vulnerable contexts; small islands; rural areas; renewable energy; hybrid renewable mini-grid; access to electricity; Third Generation Solar Home Systems; business models

\section{Introduction}

This research stresses the importance of one of the Sustainable Development Goals (SDGs), Goal 7: "Ensure access to affordable, reliable, sustainable and modern energy for all" [1]. It promotes access to proper funding and the provision of safe, affordable, financially viable, and socially and environmentally acceptable energy services [2]. However, achieving the SDG7 is not, of course, an easy task. Energy is the main contributor to climate change with $60 \%$ of the total global greenhouse gas (GHG) emissions [3]. Furthermore, one-third of the world's population lives in energy poverty [4]. In 2012, the United Nations (UN) launched the Sustainable Energy for All (SE4ALL) initiative to support SDG7's targets. In other words, it was created to identify the best patterns to ensure access to modern energy systems; to double the renewable energy (RE) share in the global mix; to support energy efficiency (EE); to enhance international cooperation; and to implement sustainable energy systems in developing countries, especially in the least developed and land-locked developing countries, and in small islands developing States. In 2013, this organization declared the decade 2014-2024 as the "Decade of Sustainable Energy for All" to promote the use of renewable resources at all levels $[3,5,6]$. 
Therefore, transforming the way in which energy is produced and consumed is fundamental to eradicating poverty, fostering sustainable development, and changing the paradigm towards green economies [6]. To accelerate the transition process to modern energy systems, SE4ALL highlights how crucial it is to establish synergies between multiple actors, sectors, and industries [7], which in turn, promotes the design and testing of innovative business models, the commitment of different actors, the capacity building, and access to public and private funds [8]. In fact, the UN members together with private parties and civil society are mobilizing economic resources for the achievement of the global Agenda [9]. In 2015, during the 21st session of the Conference of the Parties (COP21) of the UN Framework Convention on Climate Change (UNFCCC), which responded to the worries brought about GHG emissions by 2020, the delegates acknowledged the need to foster the universal access to energy in developing countries with the much-needed support of the developed countries in the form of funding, technology, and training [10]. Nevertheless, it has been recognized that the progress in achieving the SDG7 is below expectations, especially in the most vulnerable contexts such as small islands and rural areas from developing countries [11]. In that sense, this article serves as a literature review of the SDG7 to support the increase in RE share on islands and access to electricity in rural communities. This research focuses on establishing the current state of the art of off-grid energy systems in these contexts. First, the technical, economic, financial, social, and environmental needs are identified to facilitate the introduction of RE. Second, the most attractive business models to spur competitiveness are identified and described. This paper is organized as follows: Section 2 summarizes the progress in achieving the SDG7; Section 3 presents the largest challenges in the most vulnerable contexts; Section 4 shows the current status of renewable energy and storage technologies; Section 5 shows the categorization of off-grid energy systems; Sections 6 and 7 describe financing and business models applied. Section 8 presents the results and discussion, and Section 9 summarizes the conclusions and policy implications.

\section{Progress in Achieving the SDG7}

The world is making progress in achieving the SDG7 but there are differences between their targets. These differences are linked to the conditions of the countries and contexts, related to policies, funding, culture, location, society implication, and others. Explanations about the progress of access to energy and modern energy services, RE share, and energy efficiency are given below.

\subsection{Access to Electricity}

The rate of electrification has increased from $83 \%$ in 2010 to $89 \%$ in 2017. This means that, around the world, the number of people without access to electricity dropped from 1.2 billion in 2010 to 840 million in 2017. Success has been mainly achieved by Central and Southern Asia (91\% of access to electricity in 2017), while Sub-Saharan Africa has the lowest level of access with only $44 \%$ [12]. These biggest differences are related to two key dimensions: geographic location and household incomes $[13,14]$. In addition to that, in Sub-Saharan Africa, this is also linked to the lack of government effectiveness and leadership in providing access to electricity. Furthermore, large energy infrastructures remain in competition with rural energy solutions because of their economic inefficiency for public and private providers [14]. Latin America, the Caribbean, and Eastern and South-eastern Asia have achieved $98 \%$ of electricity access [12]. As a rule, families from a poor country have fewer opportunities to have access to electricity than families with the same income levels living in a richer country [15]. However, only in Latin America, 12 million people, who still lack access to electricity, live in extreme poverty with less than $\$ 1.90$ US per day and mainly in the hardest-to-reach rural areas such as in the Andes and Amazonia [16,17]. Present and future challenges remain in making the electricity service affordable and reliable. For instance, an electricity consumption of $30 \mathrm{kWh} / \mathrm{month}$ has still higher costs, more than 5\% (\$4.50 US) of the poorest families' incomes [17].

Based on the Multi-tier matrix for access to a household electricity supply arranged by peak power of typical appliances (see Table 1) [18,19], to meet the gap in electricity access up to 2030, $\$ 1.5$ billion 
per year would be necessary to power a few light bulbs and charge a mobile phone at Tier 1 , whereas $\$ 50$ billion US per year would support the connection of very high power during $24 \mathrm{~h} \times 7$ days at Tier 5 (grid power) [12].

Table 1. Multi-tier matrix for access to household electricity supply $[18,19]$.

\begin{tabular}{ccccccc}
\hline & TIER 0 & TIER 1 & TIER 2 & TIER 3 & TIER 4 & TIER 5 \\
\hline Tier criteria & $\begin{array}{c}\text { Not } \\
\text { applicable }\end{array}$ & $\begin{array}{c}\text { Task lighting, } \\
\text { phone charging, } \\
\text { radio }\end{array}$ & $\begin{array}{c}\text { General lighting, } \\
\text { television, fan } \\
\text { (if needed) }\end{array}$ & $\begin{array}{c}\text { Tier 2 AND Any } \\
\text { medium-power } \\
\text { appliances (air cooler, } \\
\text { refrigerator, food } \\
\text { processor, rice cooker, } \\
\text { water pump) }\end{array}$ & $\begin{array}{c}\text { Tier 3 AND Any } \\
\text { high-power appliances } \\
\text { (washing machine, iron, } \\
\text { hair dryer, toaster, } \\
\text { microwave) }\end{array}$ & $\begin{array}{c}\text { Tier 3 AND Any very } \\
\text { high-power appliances } \\
\text { (air conditioner, space } \\
\text { heater, vacuum cleaner, } \\
\text { water heater, electric } \\
\text { cookstove) }\end{array}$ \\
\hline $\begin{array}{c}\text { Annual } \\
\text { consumption } \\
\text { (kWh) }\end{array}$ & $\mathbf{k}$ (4.5) & $3-49$ & $50-199$ & $200-799$ & $800-1999$ & 2000 or more \\
\hline
\end{tabular}

Moving forward universal energy access is not only possible by grid extension, which demands large upfront investments. In that way, private investment is required in an appropriate business environment, supplemented by effective regulations, incentives, and affordable financing. Additionally, the participation of local government and communities are also necessary for the successful design of the energy business within the framework of the global Agenda [12].

\subsection{Renewable Energy in the Global Energy Mix}

$\mathrm{RE}$ resources are harnessed by three uses of energy (electricity, transport, and heat) directly or indirectly. The global RE share of the total final energy consumption, which is the main indicator to assess the progress of the SDG7, has increased up to $11 \%$ in 2018 and it is envisaged to increase to $15 \%$ by 2030 . Worldwide, hydro, wind, and solar photovoltaic (PV) usage have increased by $56 \%$ since 2000 . For electricity generation, solar PV alone represents almost one-third of the growth rate in the last three years. Bioenergy accounts for $50 \%$ of the use of energy, especially, in transport and heat. Adopting RE share in the energy mix depends on various factors such as the availability of resources, energy policies, and the application of energy efficiency means [17,20]. Currently, 169 countries have already embraced RE policies, and continue to increase their RE targets [21]. Among countries considered as major consumers of energy, China is the largest consumer of RE resources [17] and the biggest investor country in RE with \$20.6 trillion US in the last decade [22]. India, Indonesia, Nigeria, Pakistan, and Brazil have the highest RE share due to the fact of the large consumption of traditional biomass, while Canada is characterized by hydropower harnessing. In Sub-Saharan Africa, solid biomass is largely consumed by the residential sector. On the other hand, in Latin America and the Caribbean, $30 \%$ of the RE share corresponds to hydroelectricity generation and bioenergy use in the industry and transport sectors [17]. It is worth mentioning that this region has the highest RE targets for electricity generation, which are being supported by competitive bidding processes [23].

Focusing on the electric power sector, the growth rate of RE energy consumption has reached $8 \%$ in 2016. This is explained by the recovery of Latin America from critical droughts. For instance, Brazil has an increasing hydropower generation, whose growth rate was 3.5\% in 2016 [17]. Additionally, as mentioned before, China is the global leader in RE investments [22]. This country had a record-level wind capacity in operation in 2016. Furthermore, solar PV grew by 30\% in both China and the United States between 2015 and 2016 [17]. In 2018 alone, the total installed RE capacity worldwide was 165 GW (excluding large hydro) [21]. The Middle East and Africa invested $\$ 16.8$ million US in $45 \mathrm{GW}$ of RE in 2018, the highest ever, while Latin America invested \$12.1 billion US in the same year [22].

\subsection{Improvement in Energy Efficiency}

Energy intensity is defined as the global primary energy consumption per unit of GDP (Gross Domestic Product). This indicator has improved/decreased from 5.9 MJ/US in 2010 to 5.1 MJ/US in 
2016. However, to support the SDG7, an annual average improvement of $2.7 \%$ in energy efficiency per year is still required until 2030. In this period, Eastern and Southeastern Asia presented an annual average improvement of $3.4 \%$, whereas Central and Southern Asia has improved by $2.5 \%$ per year. Here, policies have focused on establishing a link between energy efficiency actions and economic growth. On the other hand, Oceania, North America and Europe, and Latin America and Africa have shown improvements below the global rate and lagging rates, respectively. Economic structure, energy supply, and access to energy remain the reasons for these significant differences among regions. In terms of $\mathrm{CO}_{2}$ emissions, 300 million tons were avoided [17].

More efficient industry, passenger transport, and services sectors have contributed to this improvement because of advances in technologies, while the residential and agricultural sectors have presented a minimum improvement of 1\% between 2010 and 2016.

Likewise, the electric power sector has contributed to an average efficiency of electricity generation of $40 \%$ due to more efficient coal-fired and gas-fired power plants, especially, in China and India. Moreover, meeting gaps in energy access has allowed transmission networks to be improved to reduce energy losses, particularly, in the largest generation countries [17]. Nevertheless, in 2018, the International Renewable Energy Agency (IEA) reported a slowdown in improvement in primary energy efficiency, which means a rate of only $1.2 \%$. This is equivalent to only $\$ 1.6$ trillion US regarding GDP, which could have been $\$ 4$ trillion US if case efforts had followed the recommended tendency of $2.7 \%$ [24].

\subsection{What Is Still Necessary for Supporting the SDG7?}

In spite of the efforts to achieve the SDG7, there are still 840 million people without access to electricity, there is only $11 \%$ of RE penetration in the global mix, and there was a minimum improvement of $1.2 \%$ in energy intensity in 2018. Indeed, the UN High-Level Political Forum recognizes that the world's energy systems transformation is below expectations and commitments [11]. Several aspects should be reinforced to support not only the SDG7 but also the global Agenda. For clear guidance in the energy transition, political will and long-energy planning are still required to capitalize on new RE investments by the private sector [17]. Partnerships and the effectiveness of business models should be also strengthened, where civil society should be part of the decision-making process as a reflection of energy justice $[4,11,25]$. Providing fiscal and financial incentives stands out as a need for mobilizing economic resources. Similarly, gender concerns should be emphasized in energy and climate actions, as well as in the promotion of energy services for productive purposes. Lastly, affordability is still claimed as a crucial aspect to spread RE technologies and clean cooking solutions [11].

Within the framework of the SDG7, policies ought to take into account the particular needs of each context [4]. Nevertheless, four years after the COP21, in 2019, it was clear that aligning the geopolitical context of 195 countries remains a challenge, which delays the achievement of the global targets. Added to this, from 2017 up to now, there has been an increase of around 11\% in global subsidies for the use of fossil fuels, and the lobbying organization of the sector has spent hundreds of dollars to block climate change policies [21]. This has also impeded the reaching of an agreement for an international carbon market. Furthermore, most of the developing countries, for example, from the Latin America region, have embodied commitments to introduce only large RE capacities for a grid-connected mode in their Intended Nationally Determined Contributions (NDCs) [26], and specific targets to link energy access to climate change mitigation actions are still lacking. Under this scenario, in COP25, governments were called to implement strict changes in current climate policies, which demands the imperative decarbonization of the energy sector, the presence of the scientific sector to guide decision-making, and a clear pathway for new investments [27], where a holistic outlook is also required.

The political landscape, which has only focused on technical aspects and overlooked the socio-economic factor, should consider society, institutions, financing, ownership structures, and the global economy [28]. Special attention is mainly required for vulnerable communities, which are exposed to more challenging situations because of their location and level of incomes. In those contexts, 
channeling resources for clean technologies is a latent need [11]. There are suboptimal energy policies and regulations for allocating investments, institutional cooperation, and human resources [25].

\section{The Largest Challenges of the Energy Sector in the Most Vulnerable Contexts}

The concept of vulnerability has been studied to understand how it is the context's performance against social and environmental changes in several fields [29]. The truth is that the understanding of vulnerability varies depending on the area of knowledge. For instance, from a social point of view, Zarowsky et al. [30] concluded that social inequalities are based on three dimensions of vulnerability: wellbeing, degree of exposure to risk, and the capacity to face risks effectively. From an economic perspective, vulnerability is defined as the risk of a poor country to natural shocks (natural disasters, e.g., earthquakes, volcanic eruptions, floods, and droughts) and exogenous economic shocks (price volatility, international fluctuations of interest rates, slumps in external demand, etc.), which, in turn, hamper economic growth [31]. Eco-environmental scientists observed that vulnerability is reflected as the current status of eco-environment due to natural and human disturbances, which are exacerbated by climate change [32]. From the energy sector and forged by the 2030 Agenda, energy vulnerability is defined as the major challenge that threatens the economy, the environment, and society of countries worldwide including island states [33]. Here, access to energy is recognized as a key issue of energy vulnerability, where countries with a low level of energy access or strong dependency on imported fossil fuels are more vulnerable than others (energy producing countries) [34]. There are other endogenous shocks generated by political changes or political instability [31], or by a domestic economic decline that generates political vulnerability [35]. Vulnerability is the result of inequalities among diverse groups of people within a space. Therefore, to minimize its effects on the contexts, a comprehensive understanding of the factors that influence it together with local social, economic, environmental, and political conditions is required [29]. Based on these statements and given that the 2030 Agenda leads to focusing the efforts on the most vulnerable countries, including island states, the area of discussion is concentrated on the provision of electricity on both small islands and in rural areas from developing countries.

Small islands, so-called because of their population, area, or GDP, have a series of disadvantages due to their sizes such as their dependence on the external market and the lack of natural resources [36,37]. These contexts are more economically vulnerable than other countries with large areas of land (see Figure 1). This is reflected by their high degree of susceptibility to external economic impacts related to economic openness, the concentration of exports, and dependency on strategic imported products. The first inherent characteristic is conditioned by the size of the economic market, which affects exports in terms of GDP and local resources to provide goods and services. This aspect is exacerbated by the lack of economic diversification or export concentrations and the high level of energy imports [38]. Economic vulnerability is also linked to environmental issues resulting from the islands' tendency to suffer natural hazards that impact on human and biophysical systems [39-41]. Small islands are mainly located in tropical and subtropical zones exposed to volcanic activity, earthquakes, tsunamis, cyclones, heavy floods and droughts, and the effects of climate change-erosion, floods, and salinization of freshwater sources and productive land-[40,41]. On many islands, rainwater is the main source of water for human consumption, and soils are used to feed animals and grow food [36]. Economically, agriculture, fishing, and tourism are the most vulnerable sectors affected by the environmental vulnerabilities of islands and climate change [40]. In contrast, intensive fishing, agriculture, and livestock - causes of an extensive erosion of farmlands-and tourism or other economic activities can negatively impact islands' ecosystems [36,42]. Furthermore, for islands, the dependency on imported fossil-fuels and isolation of energy markets make it difficult to guarantee an energy supply. Even though islands are not the mainly responsible for climate change, these territories are the first ones that paradoxically experience its negative effects. All of these situations highlight how important it is to reduce the islands' dependency on conventional fuels and upgrade energy governance. Interestingly, their vulnerabilities such as remoteness and size and the potential flexibility of their policies make 
islands very adaptable to change unlike context with monolithic governance. Thus, the evolution of the island's energy systems can be an excellent example of innovation for on-grid large applications $[4,43]$.

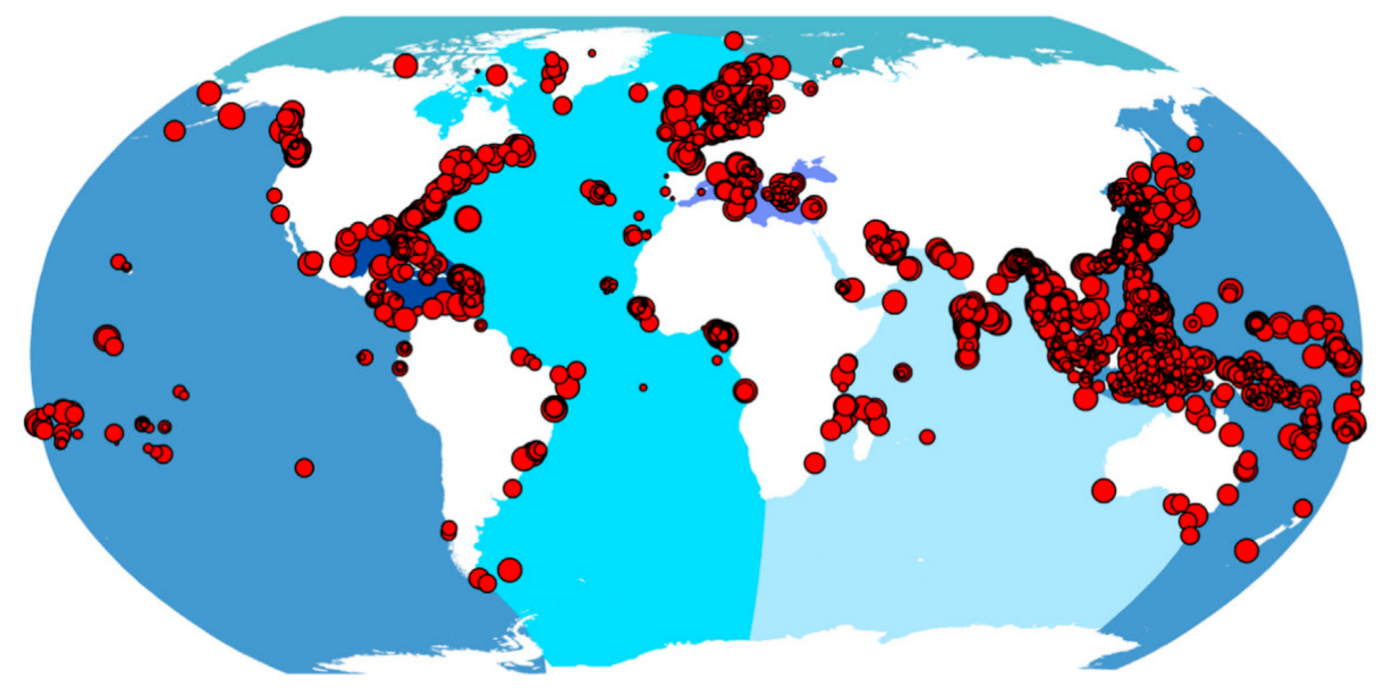

Figure 1. Map of small islands with a population of between 1000 to 100,000 inhabitants [44].

Likewise, rural areas are characterized by a low population density and a certain degree of inaccessibility—extreme in many communities—distancing from economic centers with low levels of consumption per inhabitant (see Figure 2) [45,46]. Added to this, there are fewer possibilities for employment, and agriculture is still the major economic activity. These areas are affected by the rural-urban migration of young people, which generates a demographic imbalance and leaves the older population in a vulnerable situation [45]. Here, social vulnerability is also linked to a high level of illiteracy, lack of occupation beyond activities in primary economic sectors, less diversified sources of incomes, and poor access to climate change information. Considering environmental vulnerability, these areas experience climate change impacts such as irregular rainfalls, a reduction in productive areas, shifts in harvesting seasons, and intensive droughts, which require an enhancement in adaptation means by policy-makers [47]. There is also a lack of access to services such as drinking water, sanitation, telecommunications, and electricity. The interdependence of the aforementioned factors exacerbates rural vulnerabilities, making it unprofitable to provide rural areas with an affordable and reliable electrical service. As a rule, many rural communities cannot afford to extend electricity networks or have acquired diesel generators to have access to electrical services. Therefore, the use of RE technologies offers a solution to implement resilient energy systems, interlinking them with affordability and quality $[46,48]$. For instance, access to water is key for human development and sustainable growth, thus, RE can facilitate access to water through the installation of solar pumps, reducing expenditures in fossil fuels and guaranteeing the reliability of water distribution networks [49]. It is also used for powering electrical devices to purify water to allow communities to have access to clean water, which is fit to drink [50]. In the same line, solar water-heating systems could be implemented to support many domestic and commercial activities [51]. Moreover, competition between power generation and end uses of water can be reduced through the deployment of solar PV and wind energy [49].

For both small islands and rural areas, energy is a key aspect for addressing vulnerability, which is positively correlated to GDP per capita and an improvement in the lifestyle of the population [34,38,40]. From the energy sector, this could be achieved by more resilient energy systems through the reduction in consumption of imported energy resources where RE technologies have a role to play. However, and beyond the introduction of environmentally friendly technology, solutions should be structured holistically considering a collaboration of society, economics, and governance issues. For a convincing value proposition, a mix of technologies, costs and funding, responsibilities of different partners in 
management, and operation and maintenance (O\&M) should be analyzed and discussed [52], and for the purpose of this research, the focus is on off-grid generation systems.

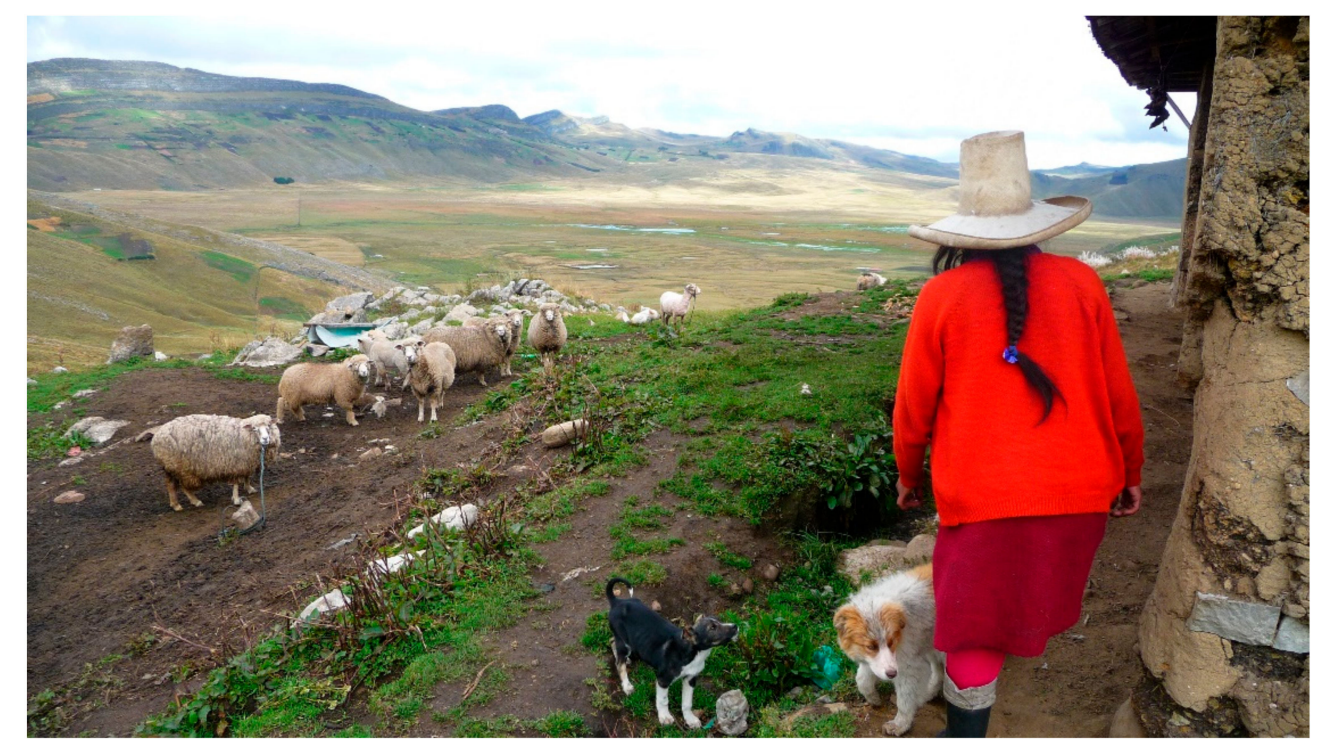

Figure 2. A rural solar user from Cajamarca, Peru. Photo: Miguel A. Egido Aguilera.

\section{Current Status of Renewable Energy Technologies for Addressing the Challenges}

Awareness of climate change and related policies has reduced international renewable energy prices, and breakthroughs in RE technologies are driving the introduction of large capacities around the world. Thus, the status of the market of RE and storage energy technologies is described in this section to understand how improvements at all levels, including prices, can address development barriers in the most vulnerable contexts.

\subsection{The Market for Renewable Energy Generation Technologies}

In 2018, the globally installed RE capacity was $2378 \mathrm{GW}$, which has increased by $8 \%$ compared to 2017, requiring an investment of $\$ 289$ billion US. From additions of renewable power (181 GW), solar PV represented 55\% with $100 \mathrm{GW}$, followed by wind (28\%) and hydro (11\%), and new capacities of fossil fuel and nuclear power plants have been outpaced [21]. Solar PV has been the technology with the greatest increase, 20\% between 2017 and 2018.

From the total capacity, $8.8 \mathrm{GW}$ corresponded to off-grid installations divided into $764 \mathrm{MW}$ of hydropower, $3 \mathrm{GW}$ of solar PV, and $5.1 \mathrm{GW}$ of other renewables [53]. New investments are more concentrated on large wind and PV plants, both grid-connected, due to falling costs of manufacturing [21,54]. On the other hand, geothermal, offshore wind, and concentrating solar power are deployed less and are even in a development phase, and their weighted-average electricity costs are in the top half of the fossil-fuel cost range [55]. Table 2 details the renewable power installed globally per technology.

Table 2. Global renewable energy capacity [21].

\begin{tabular}{ccccc}
\hline Power & Unit & $\mathbf{2 0 1 7}$ & $\mathbf{2 0 1 8}$ & Growth Rate 2017-2018 \\
\hline Renewable power capacity (including hydropower) & GW & 2197 & 2378 & $8 \%$ \\
Renewable power capacity (not including hydropower) & GW & 1081 & 1246 & $13 \%$ \\
Hydro & GW & 1112 & 1132 & $2 \%$ \\
Wind & GW & 540 & 591 & $9 \%$ \\
Solar PV & GW & 405 & 505 & $20 \%$ \\
Bio-power & GW & 121 & 130 & $7 \%$ \\
Geothermal & GW & 12.8 & 13.3 & $4 \%$ \\
Concentrating solar thermal power (CSP) & GW & 4.9 & 5.5 & $11 \%$ \\
Ocean power capacity & GW & 0.5 & 0.5 & $0 \%$ \\
\hline
\end{tabular}


According the RE investments by region in 2018, developed countries invested $\$ 136.1$ billion US, which means $11 \%$ of more investment than in 2017. Developing countries invested $\$ 61.6$ billion US with a significant participation of countries in Asia, Eastern Europe, the Middle East, and Africa. Although China invested $\$ 91.2$ billion US billion in this year, this represented a decrease of $37 \%$ compared to 2017 [21]. Given that most of the investments are concentrated in mature RE technologies such as wind, $\mathrm{PV}$, and bioenergy, their market status, including hydro energy, is described in the following sections.

\subsubsection{Hydropower}

The hydropower market presents a stability performance with higher industry competition and growing demand for energy storage. In 2018 alone, the total installed capacity achieved $1132 \mathrm{GW}$. In this year, it was noted that more than half of the installations required repairs and modernization. China led the total hydro installations with more than $35 \%$ of the total capacity, followed by Brazil, Pakistan, and Turkey. All of these countries together installed approximately 1 GW [21].

Hydropower is a site-specific technology. The global weighted-average installed cost of hydropower decreased by $16 \%$ compared to 2017; this means an installation cost of $\$ 1492 \mathrm{US} / \mathrm{kW}$ in 2018 . The Levelized Cost of Electricity (LCOE) also declined to $\$ 4.7 \mathrm{USc} / \mathrm{kWh}$ in 2018 , but increased by $29 \%$ compared to 2010 ( $\$ 3.6 \mathrm{USc} / \mathrm{kWh}$ ). It is difficult to determine the exact reasons, but in Asia (excluding China and India), the increase in cost is explained by the remote location of projects where there are more challenging (geological) conditions to connect new capacities to the grid, increasing logistical costs [55]. Furthermore, the life cycle GHG emissions of this technology are scarce. These range from 2 to $60 \mathrm{gCO}_{2 \mathrm{eq}} / \mathrm{kWh}$, with a mean of $20 \mathrm{gCO}_{2 \mathrm{eq}} / \mathrm{kWh}[56]$.

\subsubsection{Wind}

The wind industry is part of a competitive supply chain with a rising interest in offshore installations. In 2018, there was an additional wind power of $51 \mathrm{GW}$. Asia was the largest installer with $52 \%$ of the total capacity. In the offshore segment, two Asian countries together with seven European countries connected $4.5 \mathrm{GW}$. Wind technology is in a process of constant improvement which implies larger turbines, more efficiency, better outputs, and lower LCOE of wind energy production. However, the largest challenge persists in weak mechanisms (tenders) to facilitate wind deployment [21].

The global average cost of onshore wind investment has declined from $\$ 1900 \mathrm{US} / \mathrm{kW}$ in 2010 to $\$ 1500 \mathrm{US} / \mathrm{kW}$ in 2018. The reason is the reduction in the cost of wind turbines and the projects' balance costs. Wind turbines currently cost between $\$ 790 \mathrm{US} / \mathrm{kW}$ and $\$ 900 \mathrm{US} / \mathrm{kW}$ depending on their size. There are differences between countries; in China, the installed cost was $\$ 1170 \mathrm{US} / \mathrm{kW}$, and in India, it was $\$ 1200 \mathrm{US} / \mathrm{kW}$, while in the United States and the United Kingdom, it was $\$ 1660 \mathrm{US} / \mathrm{kW}$ and $\$ 2030 \mathrm{US} / \mathrm{kW}$, respectively. Then, the average LCOE was $5.6 \mathrm{USc} / \mathrm{kWh}$ in 2018. Moreover, a recent study found that the mean lifecycle GHG emissions of utility-scale onshore wind installations is $16 \mathrm{gCO}_{2 \mathrm{eq}} / \mathrm{kWh}$ [57]. As regards offshore wind farms, investment costs have decreased from $\$ 4572 \mathrm{US} / \mathrm{kW}$ to $\$ 4353 \mathrm{US} / \mathrm{kW}$ in the last eight years, but these are still high to support wide implementation [55]. Considering GHG emissions of offshore wind, the average value is approximately $13 \mathrm{gCO}_{2 \mathrm{eq}} / \mathrm{kWh}[56]$.

\subsubsection{Photovoltaics}

Photovoltaics is the most dynamic market, fostered by growing emerging markets. In 2018, solar PV increased in $100 \mathrm{GW}$ due to installations in the European Union, Mexico, the Middle East, and Africa. This new capacity compensated the slowdown suffered by China because of its policy changes to reduce PV costs and to address challenges related to grid integration. The increasing economic interest in distributed generation is also remarkable at residential and commercial levels. Given the strong political support for distributed energy in Europe, the United States, and Japan, small installations reached $41 \mathrm{GW}$ in 2018. This market is expected to keep growing in the following 
five years, especially, in China, and in the European Union, the United States, India, Japan, Latin America, and the Middle East [58].

The average PV investment cost decreased by $75 \%$ from 2010 to 2018 , which results in $\$ 1210 \mathrm{US} / \mathrm{kW}$ of a current investment price regarding large power plants. This is because of the reduction in the cost of crystalline silicon panels. For instance, in Europe, benchmark prices were between $\$ 216 \mathrm{US} / \mathrm{kW}$ for low-cost manufactures and $\$ 400 \mathrm{US} / \mathrm{kW}$ for high-efficiency modules. The Chinese and Italian markets are the most competitive with $\$ 879 \mathrm{US} / \mathrm{kW}$ and $\$ 870 \mathrm{US} / \mathrm{kW}$ for turnkey projects, respectively, while Japan presents the highest one with $\$ 2101 \mathrm{US} / \mathrm{kW}$. Then, the average LCOE was approximately $8.5 \mathrm{USc} / \mathrm{kWh}$ in 2018 [55]. Considering small PV installations (distributed generation), investment costs depend on the local regulation framework, the size of the market and the market segmentation. For example, in China, the PV installation cost for residential users ranges from between $\$ 780 \mathrm{US} / \mathrm{kW}$ to $\$ 850 \mathrm{US} / \mathrm{kW}$, while in Japan, the cost reaches $\$ 2370 \mathrm{US} / \mathrm{kW}$ [59]. In global average terms, the installation cost of distributed generation is $\$ 1432 \mathrm{US} / \mathrm{kW}$ [55]. Finally, regarding studies about the life cycle analysis of this technology, the average value of GHG emissions is $91.1 \mathrm{gCO}_{2 \mathrm{eq}} / \mathrm{kWh}$ for s-Ci systems and $30.5 \mathrm{gCO}_{2 \mathrm{eq}} / \mathrm{kWh}$ for a-Si systems [56].

\subsubsection{Bioenergy}

Bioenergy encompasses a wide range of technologies as power generation options where there are agricultural and forestry material as low-cost fuel. Furthermore, there are emerging technologies to support cost reductions in electricity generation such as biomass gasification [55]. In 2018, 9 GW of bioenergy capacity was installed globally. The leader in bioelectricity generation is China, followed by the United States, Brazil, India, and Germany. Whereas the United States and Brazil are leaders in biofuel production, which made up $69 \%$ of the total production in 2018 [21].

The worldwide average-weighted investment cost of bioenergy fell from \$2.850 US/kW in 2017 to $\$ 2100$ US/kW in 2018. However, technology costs remain higher in the United States and Europe. Developing economies of scale has been possible in China and India due to the number of bio-energy installations, with a smaller capacity than conventional thermal power plants. In this year, the global average LCOE was $6.2 \mathrm{USc} / \mathrm{kWh}, 14 \%$ lower than in 2017 [55]. Finally, as an example, biomass could emit between 75 to $650 \mathrm{gCO}_{2 \mathrm{eq}} / \mathrm{kWh}$ depending on feedstock [56].

\subsection{The Market for Storage Systems}

The electricity storage market is a crucial player in the energy transition to double the overall rate of renewable energy in the mix. In this section, the status of pumped storage systems, flywheels, and electrochemical batteries is presented.

\subsubsection{Pumped Storage System}

As regards pumped storage, the lowest cost large-scale energy storage system by far, has reached an installed capacity of $160 \mathrm{GW}$ or an energy storage value of $9000 \mathrm{GWh}$, increasing by $1.9 \mathrm{GW}$ (mainly in China, Austria, and the United States) in the last year [21,60]. Pumped storage is being optimized to incorporate variable renewables and to facilitate fast response, ensuring the stability of power systems [21]. This technology is expected to increase by $23 \mathrm{GW}$ in 2023 [60]. The main advantages of pumped storage are high technical maturity and wide operational experience, low self-discharge, a large volume of storage and long storage periods, low storage costs, and high dispatch on demand. Furthermore, its energy efficiency is between $70 \%$ and $87 \%$, making it one of the most effective ways to store energy. Among its disadvantages are low storage density, geographic restrictions and environmental concerns, and high initial investments. The market for pumped storage is not increasing at all, except for novel concepts. Thus, civil engineering techniques should be improved to take into consideration environmental concerns [61-63]. The average installation cost is $\$ 593 \mathrm{US} / \mathrm{kW}$, while the storage cost is $\$ 77 \mathrm{US} / \mathrm{kWh}$ [64]. 


\subsubsection{Flywheels}

These fast-responding mechanical storage systems are considered a mature technology, environmentally friendly, with high lifetime, power density and efficiency (over 85\%), with wide operating experience and low maintenance requirement. Nevertheless, this technology has high self-discharge rates and low energy density. This system is suitable for applications that require a shortor medium-term energy storage system $[61,64,65]$. The average cost of installation is $\$ 326 \mathrm{US} / \mathrm{kW}[64]$. The total installed capacity of this technology has increased by only 8\% from 2013 to 2015, this means a current capacity of $120 \mathrm{MW}$ [66]. This could be explained by the limited applicability of the technology and energy installation costs, which are between $\$ 1500 \mathrm{US} / \mathrm{kWh}$ to $\$ 6000 \mathrm{US} / \mathrm{kWh}$. However, these are expected to decrease between $\$ 1000 \mathrm{US} / \mathrm{kWh}$ to $\$ 3900 \mathrm{US} / \mathrm{kWh}$ [61].

\subsubsection{Battery Storage Systems}

Electrochemical battery systems can ensure the stable performance of the transmission networks and defer new investments in infrastructures. These technologies, particularly lead-acid and lithium batteries, are suitable for increasing the levels of electricity access through solar home systems (SHSs) and guaranteeing the stability of services through mini-grids in remote locations such as small islands and rural areas. The utility-scale market would increase from $10 \mathrm{GWh}(2 \mathrm{GW})$ in mid-2017 to $45 \mathrm{GWh}$ or 75 GWh in $2030[61,66]$.

Lead-acid batteries, with a wide range of applications especially in micro-grids and isolated systems, are used to guarantee and uninterruptible power service, power quality, and spinning reserve [61]. Although this technology is the least costly among energy storage systems, its cost differs according to the design, duty cycle, and lifetime [64]. Lead-acid batteries have low self-discharge rates of between $0.09 \%$ to $0.4 \%$ a day, low energy density $(50 \mathrm{Wh} / \mathrm{kg})$, and a lifetime of between three to 15 years. These systems are expected to double their cycle life from 250 to 2500 full cycles in 2016 to 540 to 5375 full cycles in 2030. Similarly, lead-acid installation costs are expected to decrease from $\$ 150-475 \mathrm{US} / \mathrm{kWh}$ in 2016 to $\$ 50-240 \mathrm{US} / \mathrm{kWh}$ in 2030 [61].

Lithium batteries, more commonly used in portable applications, present a series of advantages to lead-acid batteries such as higher energy density $(200 \mathrm{Wh} / \mathrm{kg})$, a lifetime of 10,000 cycles and high efficiency $(0.85-0.90)$. This technology is being optimized by the use of new materials, the reduction in manufacturing costs, the increase of lifetime, and the improvement in safety parameters [64]. The costs of lithium batteries range from between $\$ 473 \mathrm{US} / \mathrm{kWh}$ and $\$ 1260 \mathrm{US} / \mathrm{kWh}$ for lithium titanate batteries and between $\$ 200 \mathrm{US} / \mathrm{kWh}$ and $\$ 840 \mathrm{US} / \mathrm{kWh}$ for other lithium battery chemistries [61]. These batteries are currently the most widespread technology installed [66].

\section{Off-grid Renewable Energy Solutions for Remote Locations}

Energy is crucial for human development, sustainable economic growth, and environmental sustainability. This becomes more relevant in contexts with low possibilities of development whose markets are conditioned by size and their remote location as in the case of small islands and rural communities. The former are isolated geographically, while the latter suffer more from the lack of access to energy [67]. Globally, there are 1785 small islands worldwide whose population is between 1000 and 100,000 inhabitants (see Figure 1) [44]. In general, their power generation systems are non-interconnected with the mainland and consist of diesel power plants [68-70], which impact on electricity costs and the reliability of the electricity supply particularly while facing extreme changes in climate [68]. However, thanks to the renewable resources available in these territories, it is possible to reduce diesel consumption to accelerate the energy transition, especially through hybrid power systems. On the other hand, 840 million people lack access to electricity [12]. Rural electrification has been characterized by politicized and bureaucratic processes, mainly dependent on centralized grid extensions [71]. However, most of this population lives on low incomes and in remote rural locations (see Figure 2), where providing electricity by grid extension is technically infeasible and economically 
unprofitable. Indeed, having access to electricity has represented the installation of diesel generators for rural communities, which makes families' economy vulnerable to the volatility of fuel prices [61,72].

Therefore, for both small islands and rural communities, there is a big opportunity to address energy challenges regarding current RE prices and technological progress [70,72,73]. Off-grid systems based on renewable technologies are the least expensive way of providing access to electricity and making it affordable for the population in remote and rural areas [20,74]. Two renewable off-grid technologies, stand-alone PV systems and mini-grids (hybrid and only renewable), are crucial in helping to deliver a reliable and affordable service to vulnerable locations, especially in African countries [20]. Both energy systems are advantageous because of their rapid deployment and scalability to reach isolated populations. Off-grid systems supply a wide range of energy demand through different configurations and sizes, from solar lights to SHSs or large stand-alone solar systems to renewable mini-grids [11]. Moving forward, RE can also decarbonize other sectors, such as transport based on electric mobility programs. For instance, on small islands, the usage of electric vehicles as storage systems can allow the reduction of valleys and peaks of electric power demand to drive an effective operation of electricity generation systems [75]. In fact, it is being demanded by the least developed islands, including Small Islands Developing States (SIDS), where the lack of political will and funds remains a challenge $[76,77]$.

Table 3 offers a categorization of off-grid systems. Stand-alone systems tend to be small and involve SHSs without possibilities to grid connection, small wind turbines, and solar lighting systems. Pico, nano, micro, and renewable mini-grids or hybrid mini-grids can operate in island mode as well as the connected to the grid. Additionally, there are off-grid systems for productive purposes such as telephone towers, water pumps (wind or PV driven), and street lighting [78].

Table 3. Categorization of off-grid applications [78].

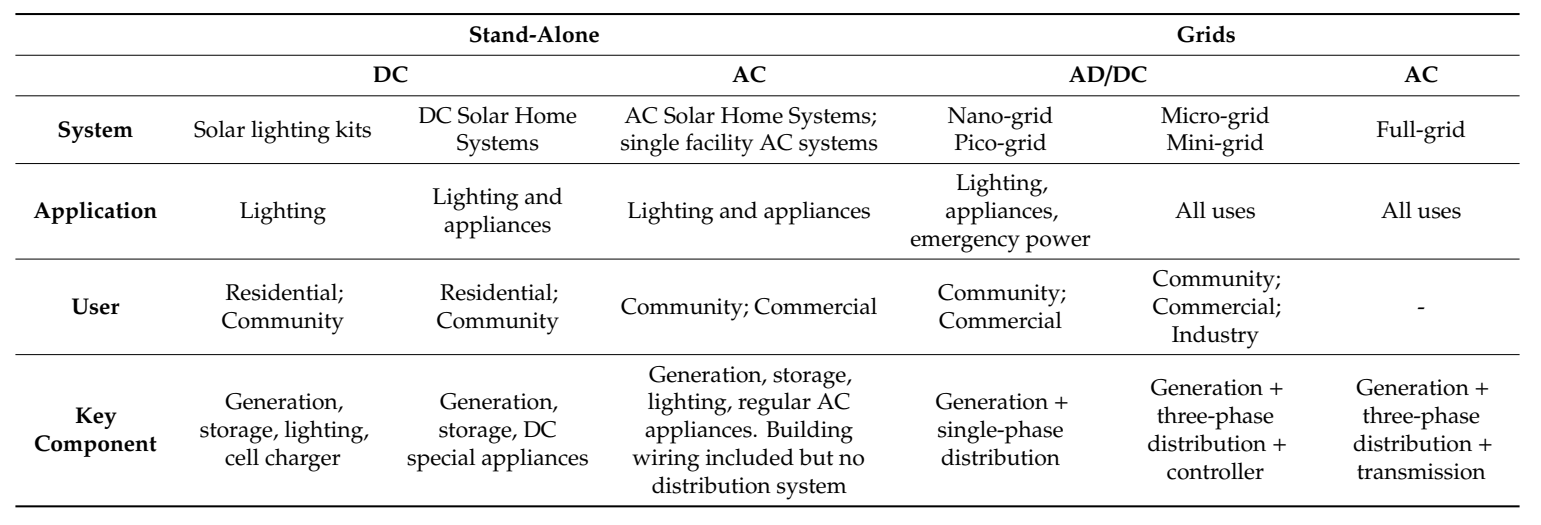

The opportunity for the off-grid market is huge when measured by the replacement or hybridization of diesel gensets. In the world, there are $400 \mathrm{GW}$ of diesel capacity among industrial facilities and mines in remote operation, back-up energy systems, and mini-grids. Some diesel generators operate as single units, whose capacity is more than $10 \mathrm{MW}$. From the global capacity of this conventional technology, between 50 and 250 GW could be hybridized with renewables [78], and approximately, $15 \mathrm{GW}$ is located on small islands [44], a chance for these territories to overcome the barriers inherent to them: insularity, size, and remoteness.

The declining costs and more efficient off-grid components based on quality standards and quality assurance certification process, including electric appliances [72], has allowed 133 million people to benefit from having access to electricity services [79]. From 2010 to 2016, only the cost of LED lights and lithium batteries dropped by $80 \%$ and $73 \%$, respectively. Currently, 100 million people are using solar lights $(<11 \mathrm{~W}), 24$ million are using SHSs $(>11 \mathrm{Wp})$, and 9 million people are connected to mini-grids [79]. The total off-grid capacity increased significantly, from $2 \mathrm{GW}$ in 2008 to $8.8 \mathrm{GW}$ in 2018. [53,79]. Here, the PV is the outstanding technology to provide electricity services in the most remote areas with $3 \mathrm{GW}$ of the overall off-grid capacity [53]. Looking forward, for energy transition 
agendas, there is no excuse in implementing affordable and innovative renewable technologies to improve the living conditions of the most vulnerable people and to reduce poverty.

\section{Financing for Implementation of Energy Generation Systems on Isolated Areas}

Renewables based on mature technologies are the lowest-cost alternative compared to conventional fossil-based power generation [17]. This is because of global targets and policies, and a renewable industry that continues to develop. In this matter, electrification finance commitments have reached a total value of $\$ 19.4$ billion US between 2013 and 2014, and $\$ 30.2$ billion US from 2015 to 2016 in high impact countries from Africa and Asia (excluding the Latin America region). Domestic sources, especially from the private sector, covered $61 \%$ of electricity finance from 2015 to 2016 . It is $22 \%$ higher than between 2013 and 2014. International funding remains the same in both periods. Public international investment decreased by 16\% from 2013-2014 to 2015-2016, whereas private international investment increased by $58 \%$ in the same period. Thirteen percent of the total funding in 2015-2016 came from Multilateral Development Banks (MDBs), which are the largest public providers [80]. The Asian Development Bank (ADB) and the African Development Bank (AfDB) have the highest portfolios dedicated to access energy. For instance, in 2014, the AfDB's portfolio registered around $26 \%$ of investments in energy access, while the World Bank Group (WB) and the Inter-American Development Bank (IADB) were more devoted to distributed energy [81]. However, all MDBs investments remain far below the benchmark in energy access and distributed energy areas [81]. What is more, in 2015-2016, only $1 \%$ of the total finance tracked was for off-grid systems for rural electrification ( $54 \%$ of investment was for grid-connected renewable technologies and $27 \%$ for grid-connected fossil fuel plants) [80].

In the case of islands, in 2018, only for those from the Pacific, the ADB established a grant portfolio for energy, comprised of 14 projects, reaching a total investment of $\$ 371$ million US with plans to extend this financing to $\$ 1$ billion US up to 2021 [82]. There is also the Small Islands Developing States Lighthouse Initiative (LHI) launched by the UN Climate Summit in 2014 that brings together 36 SIDS and partners to mobilize resources for RE. From 2014 to 2019, the LHI's partners have invested around $\$ 500$ million US to deploy renewables. In spite of the great efforts, this technology only represents $10 \%$ of the total installed capacity in SIDS [83].

Therefore, to expand the introduction of isolated renewable systems, restructuring finance programs are still necessary to surpass the barriers of high up-front costs, regulatory uncertainty, competition with conventional and pollutant technologies, and the lack of human resources in design, operation, and management [12]. Both public and private institutions have an important role in addressing the funding gap. Public investment is needed to cover public services, rural enterprises, and households that have no economic capacity to acquire off-grid technologies, as well as establishing attractive incentives for mobilizing private investment. More private funds are important as funding channels for end-users and local enterprises. However, the level of private financing varies according to the maturity of the company, the portfolio of products and services, and the stage of projects in which companies are involved. Here, banking facilities are also essential to facilitate lending for companies and end-users [79].

On one hand, from 2018 to 2030, an annual average investment of approximately $\$ 700$ billion US would be needed to increase RE capacity, and $\$ 600$ billion US to improve energy efficiency [17]. For the specific case of small islands, Blechinger et al. (2016) [44] determined that $15 \mathrm{GW}$ of diesel capacity installed on these territories could be hybridized with 7.5 GWp of PV and 14 GW of wind combined with 5.82 GWh of battery capacity to reduce 7.8 billion liters of diesel consumption and 20 million tons of GHG atmospheric emissions per year. To reduce diesel consumption and increase the RE share to approximately $50 \%$ on small islands, a total investment of $\$ 46$ billion US would be necessary. Achieving that remains a critical challenge, especially for the Pacific Islands because of their geographical fragmentation and remoteness from the mainland [84]. Furthermore, the literature has 
not identified suitable business models in these contexts to boost the introduction of RE and most of the related studies are targeted at rural areas [85-90].

On the other hand, $\$ 40$ billion US per year are needed to expand energy access to 2030 [17]. Africa and Asia have concentrated most of the investment for off-grid renewable generation systems [79]. Their high population density is an advantage for off-grid electrification [91]. Here, among their most successful business models, there is the Infrastructure Development Company Limited (IDCOL) program (2002-present). However, this program still lacks enough government support to push its electrification goals forward [92]. Conversely, the Latin America region, with fewer investment resources for the renewable off-grid systems implementation, has shown greater progress than Africa and Asia, even under more complex geographical conditions. For instance, in zones such as the Andes and the Amazonia, the rural population lives in very scattered locations and far from larger centers of population. In the 1990s, to support rural electrification, this region started to modernize its electrical power sector allowing the participation of private companies in tendering competitive process for concessions of generation, transportation, and distribution of electricity [16]. Indeed, several studies have evaluated the situation of business models applied by the region although these lack a comprehensive overview to address the vulnerabilities of the last mile population $[16,93]$. In spite of this, lessons learned from the Latin America off-grid experience would be very helpful to support initiatives in Africa and Asia. In the following section, definitions of business models are summarized.

\section{Business Models for Off-Grid Projects}

Institutional and political matters are important in determining the sustainability and success of business models, and ownership is the central factor for their classification [85-90]. Owners can be those responsible for funding the project, or operating and maintaining the generation system or making profits [94]. Thus, based on rural electrification experiences, a general definition of business models based on the management perspective is presented $[85,90]$.

\subsection{Public Model}

This model is managed by the central government or local utilities, which fund and create subsidies for projects in areas where rural electrification is non-profitable. Its main downsides are the dependence on political agendas and the lack of interest in understanding the needs of contexts. The public sector funds, installs, and oversees the O\&M of systems, and shows responsibility for the collection of fees.

\subsection{Private Sector Model}

Private involvement is part of the idea to attract funds where projects are non-profitable but receive public support through subsidies. The scalability of projects as well as incomes, potential market, and subsidies are crucial in attracting private companies, which also need high managerial and technical expertise. In this model, rural projects are driven by efficiency and performance.

\subsection{Non-Governmental Organizations (NGOs)}

NGOs work where it is not profitable to invest in rural electrification with special focus on non-grid solutions. The purpose of their intervention is highly motivated by socio-economic concerns, and projects are sponsored by bilateral or multilateral donors. After verifying that projects are fully developed, the NGOs transfer the running responsibility to communities. Nevertheless, these projects lack subsidies and enough budget, which affects the assurance of maintenance and spare parts supply.

\subsection{Community}

Communities organize themselves to set up cooperatives to own, operate, and maintain a generation system. These organizations are less bureaucratic than public utilities. However, this model 
requires long periods to acquire technical skills. There are also risks in terms of financing, social disputes related to leadership positions, payments, benefits, and technical responsibilities.

\subsection{Hybrid Model}

The hybrid model combines the aforementioned forms to address their disadvantages through the expertise of actors and enabling multiple configurations. However, the most remarkable downside is the complexity in reaching agreements and avoiding misunderstandings. This model requires stable partners to guarantee long-term projects sustainability. In accordance with the literature review, the contractual arrangements considered in this classification are: public-private partnerships, concessions, power purchase agreements, Renewable Energy Service Company (RESCO), and Energy Service Company (ESCO) $[70,85,90]$.

Apart from that, in rural electrification, there are Renewable Energy supply models that capture how technologies (systems) are transferred from suppliers to customers: (i) Service Delivery model (Fee for service model): The promoter owns the system and provides electricity service for users based on a tariff regulated by the government; (ii) Credit model (dealer model): The customer buys the system and payments are done in installments. This model involves high installations costs due to the risk in credit transactions and the quality of products; (iii) Lease model (finance leasing or hire purchase): The system is leased to the end-user-the equipment can be transferred to the customer at the end of the lease period. In any case, the owner assumes the responsibility for operation and replacement costs, while techno-economic and social assessments may vary depending on the stakeholder expertise [90,95].

Nowadays, there seems to be a common agreement in the definition of business models. However, this still lacks a clear outlook to address the main constraints in implementing off-grid renewable energy systems in vulnerable contexts. Nonetheless, what is clear is the identification of the basic elements of business models: infrastructure, value proposition, revenue model, and customer interface. The infrastructure refers to organizational matters to support the value proposition. The value proposition involves products and services offered to users. The revenue model implies incomes and expenditures associated with the commercialization of the value proposition. Lastly, the customer interface describes the relationship between providers and users $[96,97]$. Based on these statements, to support the energy transition, the role of utilities is crucial in analyzing the evolution of business models, adjusting them to local conditions, and most importantly, establishing a regulatory framework to support their implementation under concerns as regards sustainability.

In this framework, holistic and well-integrated policies and regulations for promoting off-grid solutions are also required within a complete package of key strategies for closing gaps. Added to this, there is the importance of data-based and scientific studies to support decision making and long-term planning $[17,79]$.

\section{Results and Discussion}

In this section, the main aspects to take into account in deploying RE technology on small islands and rural areas are identified. Furthermore, potential business models to support energy transition are defined.

\subsection{Off-Grid Renewable Energy Systems: Islands vs. Rural Areas}

This section sums up the main technical, economic, financial, social, and environmental needs that should be addressed to facilitate the introduction of RE in small islands and rural communities. For a better understanding, whenever possible, a comparative analysis has been included between contexts.

\subsubsection{Technology}

First, on small islands, the configuration of large power hybrid renewable mini-grids vary depending on the renewable resources and financing available (on islands, the focus is on centralized 
energy power systems). In practice, the power capacity of these generation systems ranges from between $1 \mathrm{MW}$ to $90 \mathrm{MW}$ (there is no theoretical limit for the capacity of hybrid mini-grids) [70]. Wind farms have been mainly implemented on the Atlantic Islands, whereas PV power plants have more presence on the least developed island from the Pacific $[44,67,70]$. Hydroelectricity has been mainly implemented by islands from developed countries with high elevations and hydro resource, or with possibilities to desalinate water [70]. There are also hydro generation experiences on islands with a larger population in the Pacific [98-100]; however, there are cases [73] in which the lack of political will has inhibited the study of the techno-economic and environmental feasibility. As regards biofuels and biomass, these technologies are the most expensive as it is necessary to develop studies into the internalization cost of their social and environmental benefits. Energy storage systems are crucial for both developed and developing islands. Finally, small islands from the Pacific Ocean still require their generation systems to be optimized to reduce fossil fuel dependency. Furthermore, there are good examples of the application of distributed generation in some Pacific Islands such as the Cook Islands, Fiji, and Kiribati [98]. Even though distributed generation could be a suitable alternative for islands to minimize transmission costs [68], energy planning must consider investments to adequate electrical networks for bidirectional power flows.

Second, PV technology, which is widely spread to cover small electricity needs, is the most competitive in rural areas. For contexts such as rural areas in Latin America, where the population is highly dispersed and even live far from populated centers, Third Generation Solar Home Systems (3G-SHSs) are the most reliable, affordable, and environmentally friendly alternative. Added to this, this is an end-user installation technology, which facilitates its implementation. Traditional Solar Home Systems (SHSs) that include higher PV capacities and conventional storage systems tend to be more attractive for people with more economic resources, but also require technical expertise to install them and present a larger number of failures than previous systems, which affects communities' confidence in the projects. The technological change from Second Generation Solar Home Systems (2G-SHSs) to 3G-SHSs shows that markets at the base of the pyramid are demanding more affordable and reliable technology [72].

Another important aspect related to technology is quality assurance. Quality control procedures must be a general requirement of RE projects regardless of the purpose since this has a high impact on the investment, management, social acceptability, and sustainability of projects.

\subsubsection{Economic}

Identifying economic activities is a fundamental factor in designing a proper energy generation system given its substantial relationship with the demand for electricity. For instance, small islands with attractive tourism present higher economic growths and, in turn, higher electricity consumption. From a sustainable perspective, the main economic activities of small islands should contribute to energy transition, which was demonstrated in a case study [73] by a business model proposal to fund RE projects from tourist fees. The differences in economic activities between rural areas and small islands are significant, but for both, the consideration of affordable electricity service is pivotal for energy justice. Energy providers cannot introduce an energy system that communities either cannot afford or do not need.

\subsubsection{Social}

There is a great difference in the participation of local people between islands and rural areas. The participation of islanders depends on the culture that involves a sense of locality, responsibility, and traditions in being entrepreneurs, which gets them involved in energy projects. Conversely, in the least developed islands, there is a lack of energy identity, thus, spreading awareness about the use of energy and the benefits or RE initiatives is fundamental [70]. This would support, for example, the setting up of islander communities to deploy PV projects at residential and commercial levels. Meanwhile, in rural areas [72], local participation is understood as a component of projects to guarantee 
sustainability since projects are being extended based on confidence. This is why promoters should care about this aspect while designing and implementing projects. However, there is still no active role of women, when their participation must be assumed from leadership positions.

This research states the importance of involving people within a real community environment in both contexts, creating various avenues for livelihood. This gives rise to the opportunity to act as grid-connected prosumers or off-grid prosumers to manage their system and to cover and control their electricity needs.

\subsubsection{Financial}

Whereas small islands from developed countries have capacity funding (public and private), access to finance has been a permanent issue for small islands from developing countries, which have mainly relied on funds from international cooperation, limiting private investment. This is a result of weak and protectionist policies and the lack of innovative regulations and capacities. For a better explanation, two examples are described. Since 2008, European islands aim to reach high renewable energy penetration, improve energy efficiency, and reduce GHG emissions by the application of bottom-up strategies as included in the "Package on Climate Change 20-20-20" and updated in the "2050 Long-Term Strategy" [70,101]. Two more initiatives support the clean energy transition of these islands: "Clean Energy for EU Islands" [102] and "Smart Islands Initiative" [103]. Furthermore, small European islands considered as role models for larger systems, assume new goals such as building new grid connections [101,104]. On the island of El Hierro, $100 \%$ of renewable penetration was achieved by adding alternative energy production such as wind, hydroelectric, and pumped storage technologies (2014). This project has been supported by a public-private business model and the application of incentives such as tendering, auctions, and standard subsidies [70]. For that purpose, Law 54/1997 recognized the necessity of specific regulation for these contexts, Law 24/2013 encourages the integration of renewable energy systems to reduce electricity costs, and Royal Decree $378 / 2015$ states the financial regime for remuneration of power-generating units [105]. Contrary to that, in the least-developed islands such as the Galapagos archipelago, in 2008, the Ecuadorian government launched the Zero Fossil Fuel Initiative to support the sustainable development of these islands and biodiversity protection. However, this initiative lacks a clear roadmap to drive renewable energy implementation and environmental conservation. Here, RE projects have been funded by donor countries (e.g., Germany, Japan, and Korea) and cooperation agencies. Indeed, in 2007, the only one project (San Cristobal wind farm-tariff of $12 \mathrm{USc} / \mathrm{kWh}$ ) implemented by private funds based on a concessionaire scheme was transferred to the local public electric company [70]. Furthermore, in 2013, Regulation 001/13 was enacted to finance PV power plants via a feed-in tariff mechanism (40 USc/kWh) with no success from the private side [106]. In 2018, a PV microgeneration regulation was launched to spread distributed generation at the urban level. Nevertheless, thus far, there are only two users interested in its application [73].

On the other hand, from the user perspective, islanders could become prosumers based on the energy citizen community concept recently embodied by the European Union that reflects wide experience into its application. The limitation of this new model arises from low electricity tariffs (highly subsidized) and the lack of awareness about energy and climate in the least developed islands [70,73]. Meanwhile, in rural areas, according to experiences analyzed from Latin America [72], there is a combination of different actors to fund the projects. Public and private sectors, multilateral banks, and donor agencies support initial investment although this remains a concern for the projects' extensions. Similarly, from the user point of view, being an off-grid prosumer is highly scalable and, at the same time, users' subsidies (applied in tariffs or equipment) are considered a catalyst to off-grid markets [72]. The conception of subsidies in both cases (small islands and rural areas) establishes a significant difference in the attractiveness to investors because of sustainability issues. 


\subsubsection{Environmental}

The introduction of RE is key for environmental care and the mitigation of climate change, reducing $\mathrm{CO}_{2}$ emissions. It is also key for resilience, and pinpointing the technological introduction should be adapted to local circumstances. For small islands, the use of land for large power systems such as PV or wind and its impact on the ecological value must be considered in the energy planning. Similarly, biofuel harnessing gives rise to a possible competition between the use of land for agriculture or energy production, as well as the limitation of land on islands for this purpose. Furthermore, if this resource is not produced locally, the impact on electricity generation costs is higher. In any case, the lack of studies into the cost internalization of environmental benefits of biodiesel makes its promotion infeasible $[70,73]$. These matters justify the importance of concern into the environmental impacts and benefits for a consistent RE introduction. In rural areas, 3G-SHSs not only drive environmental issues but also social benefits through the replacement of conventional energy to meet basic electricity needs [72].

Beyond that, environmental concerns also advocate bringing synergies between energy transition and circular economy [107], which could be attained by optimizing resources through the disposal of batteries at the end of their life cycle and the promotion of energy efficiency. This tackles manifold challenges, especially in developing countries, where the circular economy has received insufficient attention [108].

\subsection{Business Models for Off-Grid Renewable Solutions in the Most Vulnerable Contexts}

Based on past experiences, the scientific community has defined each typology of business model in a rigid manner [85-88,90,109]. For example, the public business model definition states that national governments are unique funders, without the proper identification of public financing sources, leaving an information gap to understand difficulties in obtaining funds in some cases. Furthermore, there is a lack of integration of the four pillars of business models: management, products, customer interface, and financing [97]. These definitions should be more consistent rather than general to address contextual concerns related to environmental, economic, and social conditions. Additionally, defining a unique business model to support off-grid renewable electrification is not possible due to a wide range of local circumstances; in other words, there is no one-size-fits-all. For instance, business models are influenced by the technologies selected, the population scope, or demand [90,97]. At the same time, it is clear that business models led by only one actor are not addressing shortcomings for the introduction of renewable off-grid solutions. Thus, this section focuses on offering a new overview of mixed business models in small-island contexts as well as rural electrification experiences based on an extensive review of literature [70,72,73,85-88,110-112]. The results of this review confirm that supporting the SDG7 demands not only the participation of multiple actors but also a combination of innovative and successful business models beyond organizational and ownership matters.

For the successful implementation of off-grid RE solutions in fragile environments, well-designed business models that consider local conditions are necessary. According to the most recent literature analyzed [70,72,73], a hybrid business model results from the participation and commitment of multiple actors, and a combination of different business models to support policies, financing, technological implementation and quality, capacity building, social and environmental concerns, and projects sustainability in a long-term. Hybrid business models are most successful on small islands from developed countries and rural areas. However, in rural areas, these are still lacking governmental support and financing assurance since the funds provided by multilateral banks or donors are not enough to cover the total gap in access to electricity. In small islands from developing countries, the government is usually reluctant to consider private participation, relying more on international donations, and sacrificing, to a certain extent, the opportunity for a long-term perspective. From an organizational perspective, multiple actors can be involved in off-grid projects, where the public sector acts as a leader of initiatives. Among partners and/or funders, there are the private sector, cooperation agencies, multilateral banks, local banking, and the scientific community. Their participation is 
focused on expertise, a development agenda, and business. These are in charge of covering the initial investment or giving financing facilities for the local population to acquire RE technology. There is also the participation of the local population (islanders or rural communities) as a key partner in the energy transition to build energy and environmental motivations, awareness, and confidence in projects through derived business models. Local inhabitants should be well-trained in management and technology, but this is difficult to achieve especially in small developing islands. Donors and international entities are devoted to supporting developing countries or regions. Whereas the scientific community enhances innovation and constant improvements according to the evolution of RE markets, and its participation is more prominent in small developed islands. From the value proposition, technology and services are implemented according to the resources, funds, and incentives available. Innovation is a driver to improve efficiency and guarantee the technical quality of projects. However, most RE projects in developing contexts do not integrate this factor within the design of business models, where a scientific community and private entities play a pivotal role. Depending on the technology, complementary business models can be implemented, such as Pay-As-You-Go (PAYG) in rural areas to manage fees and O\&M tasks. Referring to revenues, related business models and mechanisms are mainly for profitability, but in fragile environments, this also tackles affordability through tariffs and subsidies to support people's investments. Richter (2012) [96] affirms that revenue mechanisms could be easily adapted by the utilities, but, in reality, this is only possible with high political will. However, enacting adequate legislation and regulation is still required (e.g., to support fee-for-service and microcredits through local banking facilities). Finally, the customer interface is characterized by the active participation of local people assuming different roles, such as: (i) a channel of communications between promoters and communities; (ii) communal leaders/technicians to share knowledge and awareness and to spread confidence in projects; and, (iii) owners and managers of their energy systems. Here, microfranchising and citizen energy communities are the best examples to involve local inhabitants in RE projects, and both business models can be adapted to specific contexts [72,73]. Nevertheless, a wide social awareness of energy is still lacking, which limits the efficient consumption of electricity. Table 4 sums up the advantages and disadvantages of hybrid business models in vulnerable contexts.

There is a wide variation of hybrid business models in vulnerable contexts, and major barriers are observed in the least developing islands because of their protectionist policies. Policies could be redirected to integrate more actors in energy transition with international cooperation support. Energy transition requires a profound change in the perspective of energy planning for greater involvement of people and the private sector to get better outcomes. Similarly, opportunities are identified in different dimensions: (i) the diversification and leverage of funds, (ii) technical quality assurance, which is of the utmost importance in developing a value proposition, (iii) social entrepreneurship, and (iv) extensive awareness campaigns and capacity building. This requires greater receptivity to change from public institutions. 
Table 4. Pros and cons of hybrid business models in vulnerable contexts (own elaboration).

\begin{tabular}{|c|c|c|c|c|c|c|}
\hline & \multicolumn{4}{|c|}{ Small Islands } & \multirow{2}{*}{\multicolumn{2}{|c|}{ Rural Areas }} \\
\hline & \multicolumn{2}{|c|}{ Most Developed Islands } & \multicolumn{2}{|c|}{ Least Developed } & & \\
\hline \multirow[t]{2}{*}{ Goal } & \multicolumn{2}{|c|}{$\begin{array}{l}\text { Increasing RE share, mitigation of climate change, reduction } \\
\text { in fossil fuel consumption, and reduction in the price of } \\
\text { electricity }\end{array}$} & \multicolumn{2}{|c|}{$\begin{array}{l}\text { Increasing RE share, mitigation of climate change, reduction in } \\
\text { fossil fuel consumption, reduction in the price of electricity, and } \\
\text { improvement in access to electricity }\end{array}$} & \multicolumn{2}{|c|}{$\begin{array}{l}\text { Increasing the level of access to electricity, and improving the } \\
\text { living conditions of people }\end{array}$} \\
\hline & Pros & Cons & Pros & Cons & Pros & Cons \\
\hline \multirow{10}{*}{ Management } & Public-private participation & $\begin{array}{l}\text { In most cases, low } \\
\text { participation of the } \\
\text { scientific sector }\end{array}$ & $\begin{array}{l}\text { Leadership by the } \\
\text { public sector }\end{array}$ & $\begin{array}{l}\text { Difficulties in establishing solid } \\
\text { alliances in the public sector at } \\
\text { vertical and horizontal levels }\end{array}$ & Public-private participation & $\begin{array}{l}\text { Public support is } \\
\text { still required }\end{array}$ \\
\hline & Committed partners & & $\begin{array}{l}\text { Support from } \\
\text { international cooperation }\end{array}$ & $\begin{array}{l}\text { Ineffective international cooperation } \\
\text { in terms of capacity building and } \\
\text { exchange of experiences }\end{array}$ & $\begin{array}{l}\text { Support from international } \\
\text { cooperation }\end{array}$ & $\begin{array}{l}\text { Low participation of the } \\
\text { scientific sector }\end{array}$ \\
\hline & Confidence & & & Limited private participation & $\begin{array}{l}\text { Support from } \\
\text { multilateral banks }\end{array}$ & $\begin{array}{l}\text { Lack of support of the } \\
\text { local banking }\end{array}$ \\
\hline & $\begin{array}{l}\text { Easy adaptability of } \\
\text { business models }\end{array}$ & & & $\begin{array}{l}\text { Lack of participation of the } \\
\text { scientific community }\end{array}$ & Committed partners & \\
\hline & $\begin{array}{l}\text { Participation of the } \\
\text { research sector }\end{array}$ & & & $\begin{array}{l}\text { Lack of continuity of } \\
\text { concessionary models }\end{array}$ & Confidence & \\
\hline & Substantial agreements & & & $\begin{array}{l}\text { Inadequate transfer of knowledge } \\
\text { from implementing partners to local } \\
\text { technicians }\end{array}$ & Flexible business models & \\
\hline & Human resources & & & $\begin{array}{l}\text { Lack of sufficient local capacities at } \\
\text { institutional and technical levels }\end{array}$ & Substantial agreements & \\
\hline & Assurance of O\&M & & & $\begin{array}{l}\text { Lack of EE means or } \\
\text { poor application }\end{array}$ & Assurance of O\&M & \\
\hline & Reduction in LCOE & & & $\begin{array}{l}\text { Competition between RE and energy } \\
\text { access goals }\end{array}$ & Affordability & \\
\hline & $\begin{array}{l}\text { EE means as a complement } \\
\text { of RE projects }\end{array}$ & & & & & \\
\hline \multirow{5}{*}{ Financing } & Public-private funds & $\begin{array}{l}\text { Competition with pollutant } \\
\text { energy systems }\end{array}$ & Public funds & Lack of/limited private investment & Public-private funds & $\begin{array}{l}\text { Financial shortcomings } \\
\text { because of policies }\end{array}$ \\
\hline & Dedicated financing & High up-front costs & $\begin{array}{l}\text { International funds from } \\
\text { cooperation }\end{array}$ & High up-front costs & Dedicated financing & \\
\hline & Attractive incentives for RE & & & Very limited private funds & $\begin{array}{l}\text { International funds from } \\
\text { cooperation and multilateral } \\
\text { banking organizations }\end{array}$ & \\
\hline & & & & $\begin{array}{l}\text { Limited schemes to fund RE projects } \\
\text { and high subsidies for fuel }\end{array}$ & $\begin{array}{l}\text { Cross-subsidies and } \\
\text { microcredits }\end{array}$ & \\
\hline & & & & $\begin{array}{l}\text { Investments mostly focused on large } \\
\text { power plants }\end{array}$ & $\begin{array}{l}\text { Constant improvements to } \\
\text { cover transportation costs }\end{array}$ & \\
\hline
\end{tabular}


Table 4. Cont.

\begin{tabular}{|c|c|c|c|c|c|c|}
\hline & \multicolumn{4}{|c|}{ Small Islands } & \multirow{2}{*}{\multicolumn{2}{|c|}{ Rural Areas }} \\
\hline & \multicolumn{2}{|c|}{ Most Developed Islands } & \multicolumn{2}{|c|}{ Least Developed } & & \\
\hline & Pros & Cons & Pros & Cons & Pros & Cons \\
\hline \multirow{3}{*}{ Value proposition } & Advanced technology & $\begin{array}{l}\text { Insufficient information } \\
\text { about technical } \\
\text { quality procedures }\end{array}$ & & $\begin{array}{l}\text { Weak energy storage and } \\
\text { control systems }\end{array}$ & Tecnological innovation & \\
\hline & $\begin{array}{l}\text { Innovation in } \\
\text { control systems }\end{array}$ & & & $\begin{array}{l}\text { Technology is not always adapted to } \\
\text { local circumstances }\end{array}$ & Adaptability to needs & \\
\hline & & & & Lack of technical quality procedures & $\begin{array}{l}\text { Application of technical quality } \\
\text { standards }\end{array}$ & \\
\hline \multirow{3}{*}{ Customer interface } & $\begin{array}{l}\text { The involvement of the } \\
\text { local population raises } \\
\text { cooperative } \\
\text { business models }\end{array}$ & $\begin{array}{l}\text { Few examples of } \\
\text { local participation }\end{array}$ & & $\begin{array}{l}\text { Lack of communication } \\
\text { with communities }\end{array}$ & $\begin{array}{l}\text { High participation of } \\
\text { local communities }\end{array}$ & $\begin{array}{l}\text { Limited participation of } \\
\text { women as entrepreneurs } \\
\text { and local leaders }\end{array}$ \\
\hline & Assurance of revenues & & & $\begin{array}{l}\text { Lack of/low awareness about energy } \\
\text { and climate }\end{array}$ & $\begin{array}{l}\text { Job creation and promotion of } \\
\text { entrepreneurship }\end{array}$ & \\
\hline & $\begin{array}{l}\text { Committed population to } \\
\text { RE and EE means }\end{array}$ & & & Scarce local commitment & Inclusiveness & \\
\hline
\end{tabular}

RE, renewable energy; EE, energy efficiency; O\&M, operation and maintenance; LCOE, Levelized Cost of Electricity. 
Given the size of these markets, well-planned and implemented initiatives to create sustainable and resilient energy systems would send a strong message to the international community. Along the same line, this research identifies the most potential business models to support the SDG7, highlighting that the definition of the ESCO, microfranchising, and PAYG models is in accordance with the findings of this review. The potential business models are defined below:

- Auction is a tender scheme to procure a certain capacity of renewable-based energy systems in a well-planned, cost-efficient, and transparent manner. Their main characteristics are (i) flexibility in the design based on local conditions, e.g., on the maturity of the electric power market, (ii) potential for bringing out the real price of renewable technology under competitiveness, (iii) capacity to control prices and quantities of RE required by revenue guarantees, and (iv) commitment and transparency reflected by a contract in which the obligations and commitments of each party are clearly established [113].

- Citizen energy community is characterized by the complementarity of different energy sources, flexibility, the interconnectivity of different actors and bi-directionality of energy flows [114]. This model has a democratic functioning, and its goal is to provide environmental, social, and economic benefits rather than financial profits, stating that responsibilities and rights of the members must be fully respected [115].

- The ESCO model reveals itself as the most appropriate alternative to boost energy access under a regulated and transparent energy market. This model can cover investment and derived activities of off-grid electrification such as O\&M. Electricity fees, which are supported by cross-subsidies (based on a fee-for-service model) to guarantee affordability and reduce inequalities in communities, are designed in a collaborative environment in which the public sector is advised by private or other stakeholders. From an organizational perspective, this model has the potential to attract private, public international and cooperation funds for the implementation of off-grid projects.

- Microfranchising, in the energy access sector, is a model driven by entrepreneurship to provide products (e.g., electrical appliances) and support O\&M tasks, fee collection, and communication, and above all, to contribute to local development through the creation of jobs. Microfranchisees are leaders and technicians well-trained to guarantee a quality of service, which, in turn, helps to build confidence in off-grid projects and promoters. The biggest challenge of this model is to increase product sales to ensure money flow for the project. However, its greater opportunity is the involvement of local people, especially women and governments, as microfranchisees, while the flexibility of adaptation is its most important characteristic.

- The PAYG is a technological model based on banking facilities to support rural electrification projects. This model can be implemented as long as SHSs include communications systems (e.g., 3G-SHSs). It is a successful mechanism in reinforcing management efficiency through fee collection and operational activities such as maintenance work and enabling/disabling electricity service. PAYG is a complementary model of microfranchising, fee-for-service models, and also of microcredit schemes.

The implementation of these models is linked to local conditions and willingness of decision-makers to spur competition and reduce entry barriers for stakeholders. This is why policy implications for decision-makers are presented in the next section.

\section{Conclusions and Policy Implications for Decision-Makers}

The 2030 Agenda is of course far from achieving its targets due to the substantial shortcomings that the most vulnerable contexts are also facing. This mainly refers to issues in building up financing, the lack of effective regulations to encourage competitiveness and to create an appropriate environment for RE, and the poor participation of the local population. Involving people in energy transition has been widely promoted, but this has received less importance by most governments. Energy measures 
should be more consistent and holistic and must be accompanied by a clear vision of how to achieve the SDG7, regarding the characteristics of each context. Hence, policy recommendations are given to address these concerns that are exacerbated by large global imbalances and inequity.

The definition of public policies for small islands from developed countries is clearly linked to a coherent domestic government with global targets about energy transition and climate change. The process in the introduction of RE depends on a complete package of initiatives in which RE and EE means are well-integrated. However, there are only few examples in which islanders are called to be part of these initiatives, showing their responsibility for energy and nature and even being part of the investments. Furthermore, some islands, for example, from the European Union, have a conflict between self-resilience goals and policies in energy connectivity and the integration of markets. Some governments have used integration policies to argue against RE even on small and de-centralized scales due to spatial issues and high population densities, preferring to boost fuel-based exchanges [116]. There is still a debate on how to be more precise in finding decisive and more environmentally sustainable solutions in the energy sector, minimizing the degree of dependence. Nonetheless, this also reflects that most decisions focus on economic aspects and the influence of traditional energy markets, which require a major commitment of local governments and inhabitants to support a real transformation to green economies. As regards small islands from developing countries, these are more inefficient in achieving their targets. Conservative policies hinder private participation and mean a high dependency on donor nations, who also support their own companies in deploying RE projects, limiting the participation of private parties as potential funders and partners. This also has led to weak agreements, lacking adequate pricing and regulation structures [117]. Insufficient resources in developing countries mean that international cooperation will continue to be a significant stakeholder in the energy transition. Based on that, a restructuring of international cooperation agendas is required together with local targets, enhancing governmental commitment to building an appropriate environment for a green energy future, enabling incentives and auditing electricity prices, matching global policies in energy and climate, integrating local inhabitants as real agents of change, and fostering energy democratization and justice. Furthermore, RE and EE initiatives should be linked to accelerating progress. For a general point of view, most islands have preferred to install large RE capacities making it evident that this might not be the most appropriate solution. Energy policies should analyze the benefits and effects on the environment and biodiversity together with spatial governance to figure out the best RE configuration and system. The distributed generation and related business models should be studied to address the barriers and to develop economies of scale. Energy plans on islands should be a task for the representatives of national governments along with local authorities and society to tackle opportunities, barriers, and the needs of the contexts.

In rural areas, specifically from Latin America, public policies rely on concessionary schemes for access to electricity, and funding mainly depends on international cooperation and multilateral banks. Even though great progress has been detected to contribute with potential solutions in this field, governmental support is still required to build an effective political framework and regulations for the extension of the projects. Cooperation agendas for development and international funding portfolios must be restructured to channel their interventions and funds adequately, and rethinking their assistance-oriented model, respectively. Unlike with small islands, here, subsidies for RE users are considered a catalyst for global solutions. This facilitates the implementation and sustainability of projects, making rural electrification more attractive for private funders and most importantly, making the electricity service affordable for the population at the base of the pyramid. Even though the costs of RE technologies, especially for PV, are dropping due to technological advances, the impoverished conditions in which people live make it difficult to access technology; therefore, public support is essential for the creation of subsidies.

More pragmatic approaches for rolling out off-grid renewable technologies are necessary, and local agendas should be designed in a comprehensive way to enable and maintain a stable and attractive environment for investments while ensuring the long-term reliability of energy systems. Policies must 
consider local conditions at all levels such as environmental, social, economic, and cultural. The key is to highlight the link between energy, society, and the environment. Related targets must be also included in national commitments to the 2030 and climate agendas to apply for a wide range of funds. International cooperation must have a guiding role in energy policies, promoting the exchange of experiences and knowledge to support capacity building and attract private investments. The public sector has a leading role and must adopt energy identity to prioritize actions, technologies, funds, incentives, and subsidies channeling. Private parties can provide funds, ensure technological introduction, implement the following of quality standards, and build capacities through technical training. Regarding local participation, experiences from case studies in rural areas show that people are keen to support energy initiatives, standing out that bottom-up strategies are more crucial than ever. To sum up, innovation in business models can be also improved regarding technological breakthroughs and the consideration of local barriers that need to be addressed. Multi-stakeholder partnerships and the combination of business models must go further to add benefits in financing and management. Auctions, the ESCO model, citizen energy communities, microfranchises, and PAYG are positioned as the most powerful alternatives to address the gap in achieving the SDG7's targets and to spur competitiveness, driving a nexus among energy, environment, and society.

Author Contributions: Conceptualization, A.A.E.-A. and M.A.E.-A.; methodology, A.A.E.-A. and M.A.E.-A.; investigation, A.A.E.-A. and M.A.E.-A.; resources, A.A.E.-A. and M.A.E.-A.; writing-original draft preparation, A.A.E.-A.; writing - review and editing, A.A.E.-A. and M.A.E.-A.; supervision, M.A.E.-A. Both authors have read and agreed to the published version of the manuscript. All authors have read and agreed to the published version of the manuscript.

Funding: This research has been funded by the Renewable Distributed Generation and Intelligent Control (GEDIRCI) research group of the Solar Energy Institute (Instituto de Energía Solar).

Acknowledgments: The authors are grateful to Marta Victoria, Philipp Blechinger, Juan Carlos Solano, and Enrique García for their valuable comments and support.

Conflicts of Interest: The authors declare no conflict of interest.

\section{References}

1. United Nations. Sustainable Development Goals: 17 Goals to Transform Our World. Available online: http://www.un.org/sustainabledevelopment/ (accessed on 30 January 2017).

2. United Nations. The Future We Want; United Nations: Rio de Janerio, Brazil, 2012.

3. United Nations Goal 7. Affordable and Clean Energy. Available online: https://www.un.org/ sustainabledevelopment/energy/ (accessed on 23 February 2020).

4. Villavicencio, P.; Mauger, R. The UN's new sustainable development agenda and renewable energy: The challenge to reach SDG7 while achieving energy justice. J. Energy Nat. Resour. Law 2017, 36, 233-254. [CrossRef]

5. United Nations. Promotion of New and Renewable Sources of Energy; United Nations: New York, NY, USA, 2013. Available online: https://undocs.org/en/A/RES/67/215 (accessed on 5 May 2020).

6. United Nations. United Nations Decade of Sustainable Energy for All; United Nations: New York, NY, USA, 2013. Available online: https://www.un.org/ga/search/view_doc.asp?symbol=A/68/309\&Lang=E (accessed on 5 May 2020).

7. Sustainable Energy for All. High Impact Opportunities. Available online: http://www.se4all.org/actionscommitments/high-impact-opportunities (accessed on 2 February 2017).

8. Sustainable Energy for All. Clean Energy Mini-Grids. Available online: http://www.se4all.org/hio_cleanenergy-mini-grids (accessed on 2 February 2017).

9. Büyüközkan, G.; Karabulut, Y.; Mukul, E. A novel renewable energy selection model for United Nations' sustainable development goals. Energy 2018, 165, 290-302. [CrossRef]

10. United Nations. Adoption of the Paris Agreement; United Nations: Paris, France, 2015.

11. United Nations. Accelerating SDG7 Achievement. Policy Briefs in Support of the First SDG7 Review at the UN High-Level Political Forum 2018; United Nations: Washington, DC, USA, 2018. 
12. World Bank; ESMAP; SE4ALL. State of Electricity Access Report; World Bank (WB); Energy Sector Management Assitance Program (ESMAP); Sustainable Energy for All (SE4ALL): Washington, DC, USA, 2017.

13. Jimenez, R. Rural Electricity Access Penalty in Latin America: Income and Location; Inter-American Development Bank (IDB): Washington, DC, USA, 2016.

14. Onyeji, I.; Bazilian, M.; Nussbaumer, P. Contextualizing electricity access in sub-Saharan Africa. Energy Sustain. Dev. 2012, 16, 520-527. [CrossRef]

15. Jimenez, R. Barriers to electrification in Latin America: Income, location, and economic development. Energy Strateg. Rev. 2017, 15, 9-18. [CrossRef]

16. Banal-Estañol, A.; Calzada, J.; Jordana, J. How to achieve full electrification: Lessons from Latin America. Energy Policy 2017, 108, 55-69. [CrossRef]

17. International Energy Agency; International Renewable Energy Agency; United Nations Statistics Division; World Bank; World Health Organization. Tracking SDG7: The Energy Progress Report; International Energy Agency (IEA); International Renewable Energy Agency (IRENA); United Nations Statistics Division (UNSD); World Bank (WB); World Health Organization (WHO): Washington, DC, USA, 2019.

18. Bhatia, M.; Angelou, N. Beyond Connections: Energy Access Redefined; Energy Sector Management Assistance Program (ESMAP); World Bank: Washington, DC, USA, 2015.

19. Multi-Tier Framework; World Bank Group; Energy Sector Management Assistance Program; Sustainable Energy for All; Scaling Up Renewable Energy Program in Low Income Countries. Ethiopia Beyond Connections: Energy Access Diagnostic Report Based on the Multi-Tier Framework; Multi-Tier Framework (MTF); World Bank Group (WB); Energy Sector Management Assistance Program (ESMAP); Sustainable Energy for All (SE4ALL); Scaling Up Renewable Energy Program in Low Income Countries (SREP): Washington, DC, USA, 2018.

20. International Energy Agency. SDG7: Data and Projections. Available online: https://www.iea.org/reports/ sdg7-data-and-projections\#access-to-clean-cooking (accessed on 29 February 2020).

21. REN21. Renewables 2019. Global Status Report; REN21: Paris, France, 2019.

22. Frankfurt School; UNEP; BloombergNEF. Global Trends in Renewable Energy; Frankfurt School of Finance and Managementl; United Nations Environment Programme; BloombergNEF: Frankfurt, Germany, 2019.

23. REN21. Renewables 2016 Global Status Report; Renewable Energy Policy Network: Paris, France, 2016.

24. International Energy Agency. Energy Efficiency 2019. Available online: https://www.iea.org/reports/energyefficiency-2019 (accessed on 8 March 2020).

25. Bruce, S.; Stephenson, S. SDG 7 on Sustainable Energy for All: Contributions of International Law, Policy and Governance. SSRN Electron. J. 2016. [CrossRef]

26. UNDP. NDC Support Programme: Latin America and Caribbean. Available online: https://www.ndcs.undp. org/content/ndc-support-programme/en/home/our-work/geographic/latin-america-and-caribbean.html (accessed on 14 April 2020).

27. KPMG. Global COP25: Key Outcomes of the 25th UN Climate Conference; KPMG International Cooperative: Basle, Switzerland, 2019.

28. World Bank. Tracking SDG7: The Energy Progress Report; World Bank: Washington, DC, USA, 2018.

29. Aksha, S.K.; Juran, L.; Resler, L.M.; Zhang, Y. An Analysis of Social Vulnerability to Natural Hazards in Nepal Using a Modified Social Vulnerability Index. Int. J. Disaster Risk Sci. 2019, 10, 103-116. [CrossRef]

30. Zarowsky, C.; Haddad, S.; Nguyen, V. Introduction Beyond 'vulnerable groups': Contexts and dynamics of vulnerability. Glob. Health Promot. 2013, 20, 3-9. [CrossRef]

31. Guillaumont, P. An economic vulnerability index: Its design and use for international development policy. Oxford Dev. Stud. 2011, 37, 193-228. [CrossRef]

32. Nguyen, K.A.; Liou, Y.A. Global mapping of eco-environmental vulnerability from human and nature disturbances. Sci. Total Environ. 2019, 664, 995-1004. [CrossRef]

33. Genave, A.; Blancard, S.; Garabedian, S. An assessment of energy vulnerability in Small Island Developing States. Ecol. Econ. 2020, 171, 106595. [CrossRef]

34. Gatto, A.; Busato, F. Energy vulnerability around the world: The global energy vulnerability index (GEVI). J. Clean. Prod. 2020, 253, 118691. [CrossRef]

35. Leeds, B.; Davis, D. Domestic political vulnerability and international disputes. J. Conflicte Resolut. 1997, 41, 814-834. [CrossRef]

36. Briguglio, L. Small Island Developing States and their economic vulnerabilities. World Dev. 1995, 23, 1615-1632. [CrossRef] 
37. Mimura, N.; Nurse, L.; McLean, R.; Agard, J.; Briguglio, L.; Lefale, P.; Payet, R.; Sem, G. Small Islands. In Climate Change 2007: Impacts, Adaptation and Vulnerability; Parry, M., Canziani, O., Palutikof, J., van der Linden, P., Hanson, C., Eds.; Cambridge University Press: Cambridge, UK, 2007; pp. 687-716.

38. Briguglio, L.; Cordina, G.; Farrugia, N.; Vella, S. Economic vulnerability and resilience: Concepts and measurements. Oxf. Dev. Stud. 2009, 37, 229-247. [CrossRef]

39. Douglas, C.H. Editorial: Small island states and territories: Sustainable development issues and strategies-Challenges for changing islands in a changing world. Sustain. Dev. 2006, 14, 75-80. [CrossRef]

40. Barnett, J.; Waters, E. Rethinking the Vulnerability of Small Island States: Climate Change and Development in the Pacific Islands. In The Palgrave Handbook of International Development; Grugel, J., Hammett, D., Eds.; Palgrave Macmillan: London, UK, 2016; pp. 731-748, ISBN 9781137427243.

41. Méheux, K.; Dominey-Howes, D.; Lloyd, K. Natural hazard impacts in small island developing states: A review of current knowledge and future research needs. Nat. Hazards 2007, 40, 429-446. [CrossRef]

42. Fernandes, P.; Pinho, P. The distinctive nature of spatial development on small islands. Prog. Plann. 2017, 112, 1-18. [CrossRef]

43. Ioannidis, A.; Chalvatzis, K.J.; Li, X.; Notton, G.; Stephanides, P. The case for islands' energy vulnerability: Electricity supply diversity in 44 global islands. Renew. Energy 2019, 143, 440-452. [CrossRef]

44. Blechinger, P.; Cader, C.; Bertheau, P.; Huyskens, H.; Seguin, R.; Breyer, C. Global analysis of the techno-economic potential of renewable energy hybrid systems on small islands. Energy Policy 2016, 98, 674-687. [CrossRef]

45. Commins, P. Poverty and social exclusion in rural areas: Characteristics, processes and research issues. Sociol. Ruralis 2004, 44, 60-75. [CrossRef]

46. Egido-Aguilera, M.A.; Camino-Villacorta, M. Guide to Standards and Technical Protocols for Rural Electrification with Renewable Energies; Universidad Politécnica de Madrid (UPM); Trama TecnoAmbiental: Madrid, Spain, 2008.

47. Dumenu, W.K.; Obeng, E.A. Climate change and rural communities in Ghana: Social vulnerability, impacts, adaptations and policy implications. Environ. Sci. Policy 2016, 55, 208-217. [CrossRef]

48. Bazilian, M.; Nakhooda, S.; Van de Graaf, T. Energy governance and poverty. Energy Res. Soc. Sci. 2014, 1, 217-225. [CrossRef]

49. International Renewable Energy Agency. REthinking Energy; International Renewable Energy Agency (IRENA): Abu Dhabi, UAE, 2017.

50. Bertheau, P. Assessing the impact of renewable energy on local development and the Sustainable Development Goals: Insights from a small Philippine island. Technol. Forecast. Soc. Chang. 2020, 153, 119919. [CrossRef]

51. Gautam, A.; Chamoli, S.; Kumar, A.; Singh, S. A review on technical improvements, economic feasibility and world scenario of solar water heating system. Renew. Sustain. Energy Rev. 2017, 68, 541-562. [CrossRef]

52. Tomc, E.; Vassallo, A.M. Community renewable energy networks in urban contexts: The need for a holistic approach. Int. J. Sustain. Energy Plan. Manag. 2015, 8, 31-42. [CrossRef]

53. International Renewable Energy Agency. Renewable Capacity Statistics 2019; International Renewable Energy Agency (IRENA): Abu Dhabi, UAE, 2019.

54. United Nations Economic Commission for Europe; German Energy Agency. Status and Perspectives for Renewable Energy Development in the UNECE Region; United Nations Economic Commission for Europe (UNECE); German Energy Agency (DENA): Berlin, Germany, 2017.

55. International Renewable Energy Agency. Renewable Power Generation Costs in 2018; International Renewable Energy Agency (IRENA): Abu Dhabi, UAE, 2019.

56. Amponsah, N.Y.; Troldborg, M.; Kington, B.; Aalders, I.; Hough, R.L. Greenhouse gas emissions from renewable energy sources: A review of lifecycle considerations. Renew. Sustain. Energy Rev. 2014, 39, 461-475. [CrossRef]

57. Dolan, S.L.; Heath, G.A. Life Cycle Greenhouse Gas Emissions of Utility-Scale Wind Power: Systematic Review and Harmonization. J. Ind. Ecol. 2012, 16, S136-S154. [CrossRef]

58. International Energy Agency. Tracking Power: Solar PV. Available online: https://www.iea.org/reports/ tracking-power-2019/solar-pv (accessed on 23 March 2020).

59. Masson, G.; Kaizuka, I. Trends 2018 in Photovoltaic Applications; International Energy Agency (IEA): Paris, France, 2018. 
60. International Energy Agency (IEA). Will Pumped Storage Hydropower Expand More Quickly than Stationary Battery Storage? Available online: https://www.iea.org/articles/will-pumped-storage-hydropower-expandmore-quickly-than-stationary-battery-storage (accessed on 16 July 2020).

61. International Renewable Energy Agency. Electricity storage and renewables: Costs and markets to 2030. In Electricity-Storage-and-Renewables-Costs-and-Markets; International Renewable Energy Agency (IRENA): Abu Dhabi, UAE, 2017; p. 132.

62. Sultan,H.M.; Zaki Diab, A.A.; Kuznetsov Oleg, N.; Zubkova Irina, S. Design and evaluation of PV-wind hybrid system with hydroelectric pumped storage on the National Power System of Egypt. Glob. Energy Interconnect. 2018, 1, 301-311. [CrossRef]

63. Rehman, S.; Al-Hadhrami, L.M.; Alam, M.M. Pumped hydro energy storage system: A technological review. Renew. Sustain. Energy Rev. 2015, 44, 586-598. [CrossRef]

64. Zakeri, B.; Syri, S. Electrical energy storage systems: A comparative life cycle cost analysis. Renew. Sustain. Energy Rev. 2015, 42, 569-596. [CrossRef]

65. Arani, A.A.K.; Karami, H.; Gharehpetian, G.B.; Hejazi, M.S.A. Review of Flywheel Energy Storage Systems structures and applications in power systems and microgrids. Renew. Sustain. Energy Rev. 2017, 69, 9-18. [CrossRef]

66. International Energy Agency. Energy Storage. Available online: https://www.iea.org/reports/trackingenergy-integration/energy-storage (accessed on 13 April 2020).

67. Neves, D.; Silva, C.A.; Connors, S. Design and implementation of hybrid renewable energy systems on micro-communities: A review on case studies. Renew. Sustain. Energy Rev. 2014, 31, 935-946. [CrossRef]

68. Kuang, Y.; Zhang, Y.; Zhou, B.; Li, C.; Cao, Y.; Li, L.; Zeng, L. A review of renewable energy utilization in islands. Renew. Sustain. Energy Rev. 2016, 59, 504-513. [CrossRef]

69. Katsaprakakis, D.A.; Voumvoulakis, M. A hybrid power plant towards $100 \%$ energy autonomy for the island of Sifnos, Greece. Perspectives created from energy cooperatives. Energy 2018, 161, 680-698. [CrossRef]

70. Eras-Almeida, A.A.; Egido-Aguilera, M.A. Hybrid renewable mini-grids on non-interconnected small islands: Review of case studies. Renew. Sustain. Energy Rev. 2019, 116, 109417. [CrossRef]

71. Hoffmann, M.M.; Pelz, S.; Monés-Pederzini, Ò.; Andreottola, M.; Blechinger, P. Overcoming the Bottleneck of Unreliable Grids: Increasing Reliability of Household Supply with Decentralized Backup Systems. J. Sustain. Res. 2020, 2. [CrossRef]

72. Eras-Almeida, A.A.; Fernández, M.; Eisman, J.; Martín, J.G.; Caamaño, E.; Egido-Aguilera, M.A. Lessons Learned from Rural Electrification Experiences with Third Generation Solar Home Systems in Latin America: Case Studies in Peru, Mexico, and Bolivia. Sustainability 2019, 11, 7139. [CrossRef]

73. Eras-Almeida, A.A.; Egido-Aguilera, M.A.; Blechinger, P.; Berendes, S.; Caamaño, E.; García-Alcalde, E. Decarbonizing the Galapagos Islands: Techno-Economic Perspectives for the Hybrid Renewable Mini-Grid Baltra-Santa Cruz. Sustainability 2020, 12, 2282. [CrossRef]

74. Deichmann, U.; Meisner, C.; Murray, S.; Wheeler, D. The economics of renewable energy expansion in rural Sub-Saharan Africa. Energy Policy 2011, 39, 215-227. [CrossRef]

75. Colmenar-Santos, A.; Linares-Mena, A.R.; Borge-Diez, D.; Quinto-Alemany, C.D. Impact assessment of electric vehicles on islands grids: A case study for Tenerife (Spain). Energy 2017, 120, 385-396. [CrossRef]

76. Eras-Almeida, A.A.; Coronel, C.B.; Chumbi, R.H. Electric Mobility for the Galapagos Islands: Establihments of Technnical Parameters. Energía 2017, 13, 213-221.

77. Soomauroo, Z.; Blechinger, P.; Creutzig, F. Unique Opportunities of Island States to Transition to a Low-Carbon Mobility System. Sustainability 2020, 12, 1435. [CrossRef]

78. Kempener, R.; Lavagne d'Origue, O.; Saygin, D.; Skeer, J.; Vinci, S.; Gielen, D. Off-Grid Renewable Energy Systems: Status and Methodological Issues; International Renewable Energy Agency: Abu Dhabi, UAE, 2015.

79. IRENA. Off-Grid Renewable Energy Solutions to Expand Electricity Access: An Opportunity Not to Be Missed; International Renewable Energy Agency (IRENA): Abu Dhabi, UAE, 2019.

80. Climate Policy Initiative, See for All. Energizing Finance 2018: Understanding the Landscape; Climate Policy Initiative (CPI); See for All (SE4ALL): Washington, DC, USA, 2018.

81. Sierra Club; Oil Change International. Still Failing to Solve Energy Poverty; Sierra Club (SC); Oil Change International (OCI): San Franciso, CA, USA, 2014.

82. Asian Development Bank. The Pacific Islands: The Push for Renewable Energy. Available online: https://www.adb.org/results/pacific-islands-push-renewable-energy (accessed on 7 May 2020). 
83. International Renewable Energy Agency. SIDS Lighthouses Initiative. Progress and Way forward; International Renewable Energy Agency (IRENA): Abu Dhabi, UAE, 2019.

84. Weir, T. Renewable energy in the Pacific Islands: Its role and status. Renew. Sustain. Energy Rev. 2018, 94, 762-771. [CrossRef]

85. Wiemann, M.; Rolland, S.; Glania, G. Hybrid Mini-Grids for Rural Electrification: Lessons Learned; Alliance for Rural Electrification (ARE); United States Agency for International Development (USAID): Brussels, Belgium, 2014.

86. World Bank. REToolkit: A Resource for Renewable Energy Development; World Bank: Washington, DC, USA, 2008.

87. Franz, M.; Peterschmidt, N.; Rohrer, M.; Kondev, B. Mini-Grid Policy Toolkit: Policy and Business Frameworks for Successful Minigrid Roll-Outs; European Union Energy Initiative Partnership Dialogue Facility (EUEI PDF): Eschborn, Germany, 2014.

88. Safdar, T. Business Models for Mini-Grids; Technical Report 9; Smart Villages; Cambridge Malaysian Education and Development Trust (CMEDT); Malaysian Commonwealth Studies Centre (MCSC); Templeton World Charity Foundation (TWCF): Cambridge, UK, 2017.

89. Moner-Girona, M.; Solano-Peralta, M.; Lazopoulou, M.; Ackom, E.K.; Vallve, X.; Szabó, S. Electrification of Sub-Saharan Africa through PV/hybrid mini-grids: Reducing the gap between current business models and on-site experience. Renew. Sustain. Energy Rev. 2018, 91, 1148-1161. [CrossRef]

90. EUEI. Sustainability_Business Models for Rural Electrification; European Union Energy Initiative (EUEI): Eschborn, Germany, 2018.

91. World Bank. Scaling Up Access to Electricity: The Case of Lighting Africa. Live Wire A Knowl. Note Ser. Energy Extr. Glob. Pract. 2014, 21, 2.

92. Almeshqab, F.; Ustun, T.S. Lessons learned from rural electrification initiatives in developing countries: Insights for technical, social, financial and public policy aspects. Renew. Sustain. Energy Rev. 2019, 102, 35-53. [CrossRef]

93. itdUPM; IMF-IDB. Sustainable Energy Distribution in Latin America; Innovation and Technology for Development Center-Technical University of Madrid (itdUPM); Multilateral Investment Fund-Inter-American Development Bank (IMF-IDB): Washington, DC, USA, 2016.

94. Hazelton, J.; Bruce, A.; MacGill, I. A review of the potential benefits and risks of photovoltaic hybrid mini-grid systems. Renew. Energy 2014, 67, 222-229. [CrossRef]

95. Mainali, B.; Silveira, S. Renewable energy markets in rural electrification: Country case Nepal. Energy Sustain. Dev. 2012, 16, 168-178. [CrossRef]

96. Richter, M. Utilities' business models for renewable energy: A review. Renew. Sustain. Energy Rev. 2012, 16, 2483-2493. [CrossRef]

97. Engelken, M.; Römer, B.; Drescher, M.; Welpe, I.M.; Picot, A. Comparing drivers, barriers, and opportunities of business models for renewable energies: A review. Renew. Sustain. Energy Rev. 2016, 60, 795-809. [CrossRef]

98. Raturi, A.; Singh, A.; Prasad, R.D. Grid-connected PV systems in the Paci fi c Island Countries. Renew. Sustain. Energy Rev. 2016, 58, 419-428. [CrossRef]

99. Brown, G. Small Hydro Transforms Fiji's Energy Mix - Renewable Energy World. Available online: https: //www.renewableenergyworld.com/2012/04/18/small-hydro-transforms-fijis-energy-mix/\#gref (accessed on 21 April 2020).

100. Government of Vanuatu Brenwei. Hydro Project. Available online: https://doe.gov.vu/index.php/projects-2/ item/8-brenwei-hydro-project (accessed on 21 April 2020).

101. European Commission. 2050 Long-Term Strategy. Climate Action. Available online: https://ec.europa.eu/ clima/policies/strategies/2050_en (accessed on 29 August 2020).

102. Clean Energy for EU Islands Secretariat. Clean Energy for EU Islands. Available online: https://euislands.eu/ (accessed on 29 August 2020).

103. Smart Islands Initiative. Available online: http://www.smartislandsinitiative.eu/en/index.php (accessed on 29 August 2020).

104. European Commission. A Carbon-Free Future for the Canary Islands Possible by 2050; European Commission: Brussels, Belgium, 2017.

105. Uche-Soria, M.; Rodríguez-Monroy, C. Special regulation of isolated power systems: The Canary Islands, Spain. Sustainability 2018, 10, 2572. [CrossRef] 
106. Eras-Almeida, A.A. Policy to Develop Renewables Energies in Ecuador; Universidad Autónoma de Madrid: Madrid, Spain, 2015.

107. Chen, W.M.; Kim, H. Circular economy and energy transition: A nexus focusing on the non-energy use of fuels. Energy Environ. 2019, 30, 586-600. [CrossRef]

108. Preston, F.; Lehne, J.; Wellesley, L. An Inclusive Circular Economy: Priorities for Developing Countries; Chatham House, the Royal Institute of International Affairs: London, UK, 2019; p. 82.

109. Chaurey, A.; Krithika, P.R.; Palit, D.; Rakesh, S.; Sovacool, B.K. New partnerships and business models for facilitating energy access. Energy Policy 2012, 47, 48-55. [CrossRef]

110. Okay, N.; Akman, U. Analysis of ESCO activities using country indicators. Renew. Sustain. Energy Rev. 2010, 14, 2760-2771. [CrossRef]

111. Lemaire, X. Fee-for-service companies for rural electrification with photovoltaic systems: The case of Zambia. Energy Sustain. Dev. 2009, 13, 18-23. [CrossRef]

112. Lemaire, X. Off-grid electrification with solar home systems: The experience of a fee-for-service concession in South Africa. Energy Sustain. Dev. 2011, 15, 277-283. [CrossRef]

113. IRENA; CEM. Renewable Energy Auctions. A Guide to Design; International Renewable Energy Agency (IRENA); Clean Energy Ministerial (CEM): Abu Dhabi, UAE, 2015.

114. Lowitzsch, J.; Hoicka, C.E.; Tulder, F.J. Van Renewable energy communities under the 2019 European Clean Energy Package-Governance model for the energy clusters of the future? Renew. Sustain. Energy Rev. 2020, 122, 109489. [CrossRef]

115. Eurelectric. Citizens Energy Communities: Recommendations for a Successful Contribution to Decarbonisation; Union of the Electricity Industry—Eurelectric aisbl: Brussels, Belgium, 2019.

116. Kotzebue, J.R.; Weissenbacher, M. The EU's Clean Energy strategy for islands: A policy perspective on Malta's spatial governance in energy transition. Energy Policy 2020, 139, 111361. [CrossRef]

117. Dornan, M.; Shah, K.U. Energy policy, aid, and the development of renewable energy resources in Small Island Developing States. Energy Policy 2016, 98, 759-767. [CrossRef]

(C) 2020 by the authors. Licensee MDPI, Basel, Switzerland. This article is an open access article distributed under the terms and conditions of the Creative Commons Attribution (CC BY) license (http://creativecommons.org/licenses/by/4.0/). 